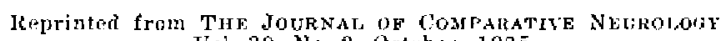
Vol. 39, No. 2, Oetuber, 1925

\title{
THE DEVELOPMEN' OF THE CEREBELLUM IN THE FROG (HYLA REGILLA) IN RELATION TO THE VESTIBULAR AND LATFRAL-LINE SYSTEMS
}

O. LARSELL

Anatomical Laboratory, University of Oregon Medical School, Portland

THLRTY-SEVEN FIGURES

CONTENTS

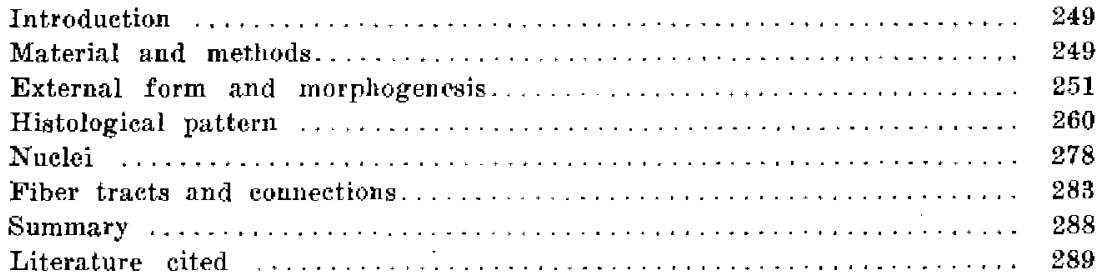

\section{INTRODUCTION}

In a recent contribution the writer ('23) has given a description of the cerebellum of the adult frog (Rana pipiens), in which was also included some account of the development of this organ in larvae of Hyla regilla. This paper was intended to prepare the way for a further study of the development of the cerebellum in the frog. A fairly detailed account of the changes that occur, and of the relations of the vestibular and lateral-line systems, during development, to the cerebellar structures should prove of value in arriving at a correct understanding of this organ.

\section{MATERIAL AND METHODS}

The present study has been based entirely on larvae and newly metamorphosed frogs of Hyla regilla (B. and G.). The species was kindly identified for me at the United States 
National Museum. It is easily available in this region, and the small size of the individuals was of aelvantage in securing large numbers of Golgi series. The standard methods of neurological technique were employed, and serial sections were cut in the three conventional planes, as indicated in the list of series which follows:

89 series by the rapid Golgi method, transverse, sagittal, and horizontal, in stages from $28 \mathrm{~mm}$. total length to newly metamorphosed frogs.

13 series stained with hematoxylin and eosin or hematoxylin and orange $G$, transverse, sagittal, and horizontal, from stages of $16 \mathrm{~mm}$. total length and upward.

15 series by the method of Ramón $y$ Cajal, transverse, sagittal, and horizontal, stages of $16 \mathrm{~mm}$. total length and upward.

11 series by the vom Rath method, transverse, sagittal, and horizontal stages of $22 \mathrm{~mm}$. total length and upward.

3 series by Nissl method, transverse, from metamorphosing tadpoles of $12 \mathrm{~mm} ., 3.5 \mathrm{~mm}$., and $1 \mathrm{~mm}$. tail length.

Four models were also reconstrueted of the rostral part of the medulla oblongata, the cerebellar region, and part of the midbrain. These were prepared by the wax-plate method of Born and the blotting paper method of Mrs. Gage. Stages measuring $16 \mathrm{~mm}$. and $18 \mathrm{~mm}$. with no legs, $25 \mathrm{~mm}$. total length with hind legs just appearing, and $23 \mathrm{~mm}$. tail length (36 mm. total length), with well-developed hind legs and fore legs, were selected for these models.

The larvae of Hyla regilla attain a total length of 42 to $44 \mathrm{~mm}$, occasionally $46 \mathrm{~mm}$, before the shortening of the tail begins which accompanies metamorphosis. At this stage of greatest length the hind legs are of small to medium size. The fore legs, while visible under a membrane, have not appeared externally. This they do after absorption of the tail has begun, when the total length of the tadpole has been reduced to 37 to $40 \mathrm{~mm}$. The young frog has a body length of 11 to $12 \mathrm{~mm}$. It is a matter of some difficulty to designate the stages, since the degree of development of the nervous system and the length of the individual specimen do not always coincide, especially in the younger stages. For pur- 
poses of description I have chosen to designate the total length of the larva, measured from rostral tip to the end of the tail, in stages up to that of maximum length, with some reference to the development of the legs. In the metamorphosing tadpoles the stage of development of the legs and the tai] length will be used as the eriteria of age, it being remembered that the shorter tail indicates the older stage. These criteria are probably not altogether accurate, since frequently tadpoles in captivity in the laboratory underwent striking changes of development within a day or two, sometimes indeed overnight, while others apparently of about the same stage of development when captured, were much slower in completing metamorphosis. Nevertheless, while recognizing the probable inaccuracy indicated, the eriteria selected appear to be sufficient for the purpose in view and are the best which can be easily applied. They are therefore used for descriptive purposes.

EXTERNAL FORM AND MORPHOGENESIS

It is well known that the cerebellum develops as a dorsal and medial growth of the rostral portion of the rhombic lip of the medulla oblongata. It is purposed to follow the details of this growth and the internal changes which take place during its progress.

In the young tadpole the roof of the rhomboid fossa is entirely membranous. At stages of 16 to $18 \mathrm{~mm}$. in Hyla, in which stages the legs are entirely lacking, there is present an oblique plate (figs. 1,3 , and $8, c b . p l$ ) in the mid-region which the cerebellum later oceupies. This membranous plate is continuous caudally with the chorioid plexus of the IV ventricle, and rostrally with the anlage of the midbrain (fig. 3 ), which is also at this stage non-nervous near the mid-plane. The membranous roof continues laterally in the cerebellar region to the rhombic lip, as shown in figures 1 and 13 . In front of the level of the $V$ root the ventricle spreads out on either side to form the recessus lateralis rhombencephali (figs. 1, $3,5,6,8,22,27$, r.l.). Continuing forward from this the 
fossa narrows rather abruptly toward the aqueduct. The most rostral part of the lateral and forward walls in the 18- $\mathrm{mm}$ stage are formed in part of massive tissue which rolls upward from the floor of the fossa (fig. 1), but the upper

\section{AIBBREVIATIONS}

a.ac.l, area acustico-lateralis
br.conj, brachium conjunctivum
cb., cerebellum
cb.pl, cerebellar plate
c.c., canalis centralis
a.ob., corpug cerebelli
co.cb., commissura cerebelli
d.a., diverticulum anterior
em.gr., eminentia granularis
em.F, eminentia trigemini
em.v., eminentia cerebellaris ventralis
f.l.m., fascieulus longitudinalig medialis
f.sol., faseiculus solitarius
gn.V, ganglion of V nerve
gn.VII l.l.d., ganglion of lateral line
VII nerve
gn.FII, ganglion of viI nerve

gn.FIII, ganglion of VIII nerve

gr., granule cell

hyth., lypothalamus

ind, infundibulum

l.akr., lobus aurieularis

l.l.l., lobus lincae lateralis

im., Iemniscus

mes., mesencephalon

$n . F$, nervus trigemini

$n_{+} V I I$, nervus facialis

n.VII l.l., nervus VII lineae lateralis

n.VIII $d$, nervus VIII dorsalis

$n, V I I I v$, nervus VIII ventralis

n.IX, nervus glossopharyngeus

$n . X$, nervus vagus

nuc. $\boldsymbol{V}$ m., nucleus motorias $\mathrm{V}$

nuc.VII m., nueleus motorius VII

n.uc.cb., nucleus eerebelli

nuc.d,moc., nucleus dorsalis magnocellu-

pl.ch., plexus chorioideus

Pur.e., Purkinje cell

$r . l$. , recessus lateralis rhombencephali

$r . V$, sensory root of trigeminus

r.F.m., radix motorius $V$

r. $F$ sp., radix spinalis $\mathrm{V}$

r. $F I I$ l.l., radix lineste lateralis VII

r.FII l.l.d., radix lineae lateralis VII dorsalis

r.VII l.l.m., radix lineae lateralig VII medialis

r.VII l.l.v., radix lineae lateralis VII ventralis

r. $P I I I$, radix VIII

$r . X l, l_{,}$, radix lineae lateralis $X$

$r . X$ l.l.v., radix lineae lateralis $X$ ventralis

s.a., stratum aIbum

$s . g$. , stratum griseum

s.l., suleus limitans

s.t.cb., suleus cerobellaris ventralis

teq., tegmantum

tr.a., dorsal longitudinal traet of area acustica.

tr.b., ventral longitudinal tract of area acustica

tr.b.t., tractus bulbo-tectalis

tr.cb.teg.b., tractus cerebellaris tegmentalis bulbi

tr.m.cb., tractus mamillo-cerebellaris

tr.sp.ob., tractus spino-cerebellaris

tr.sp.t., tractus spino-tectalis

tr.t.b., tractus tecto-bulbaris

tr.th.m., tractus thalamo-bulbaris

tr. $Y$-sp. tractus trigemino-spinalis

tr.vest.cb., tractus vegtibulo-cerebellaris

tr.vest.d., tractus vestibulo-cerebellaris direet

nuc.isth, nucleus isthmi

nuc.l.l., nucleus lineas lateralis

nuc.vest,; nucleus vestibularis

nua.vis.see, nucleus viseeralis secundus

went.III, venticulus tertius

vent.IV, ventriculus quartus

v.m.a, velum medullare anterius

pi

CC

is

a

ir

tl

$\mathrm{p}$

li 
part is membranous as elsewhere. This massive tissue is continuous with the tegmentum of the medulla oblongata, and is made up chiefly of cells at this stage. There is, however, a continuation of the stratum album of the bulb, which appears in cross-section through this level as an island of white at the outside angle formed by the swelling up of the rostral part of the floor of the fossa (figs. 5, 11, and 12, l.l.l.). A prominent furrow appears in the ventricular wall also at this level, and marks the boundary of the corpus cerebelli from the

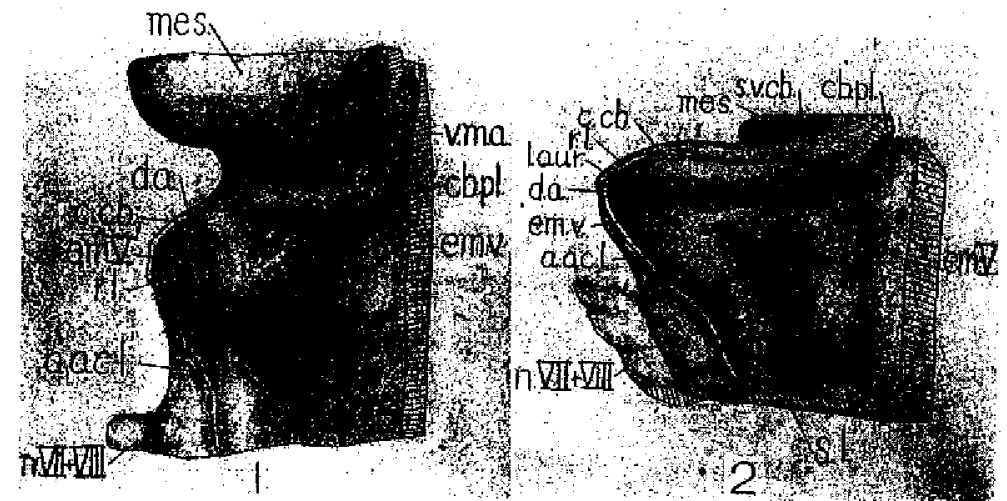

Fig. 1 Dorsal ricw of model, showing rostral region of fossa rhomboidea in $18-\mathrm{mm}$, larva of Hyla regilla, jucluding the ecrebellar anlage and part of the midbrain, $\times 96$.

Fig. 2 Dorsal view of model, showing rostral region of fossa rhomboidea and cerebellum in $25-\mathrm{mm}$. larva of Ifyla regilla, in which hind legs are just appearing as extermal buds. $\times 64$.

tegmentum. This is designated the sulcus cerebellaris ventralis (fig. 2, s.v.cb.). In the mass of tissue above this furrow may be reoggnized the anlage of the corpus cerebelli. Below the sulcus and continuing caudally lies the eminentia cerebellaris ventralis. In the $18-\mathrm{mm}$. larva this appears as a slight swelling (fig. 1, em.v.) of the floor of the lateral recess. In the $25-\mathrm{mm}$. stage (fig. 2) it is much more prominent and extends toward the mid-line, but the lateral portion is still conspicuous. By the stage of $36 \mathrm{~mm}$, however, the lateral portion of the corpus cerebelli has so increased in volume as 
to overshadow the ventral eminence laterally. The ventral sulens becomes a shallow depression, the floor of which is the transition zone between the eminentia ventralis and the corpus cercbelli.

Caudal to the ventral cerebellar eminence, and separated from it by a shallow depression in the floor of the fossa, is
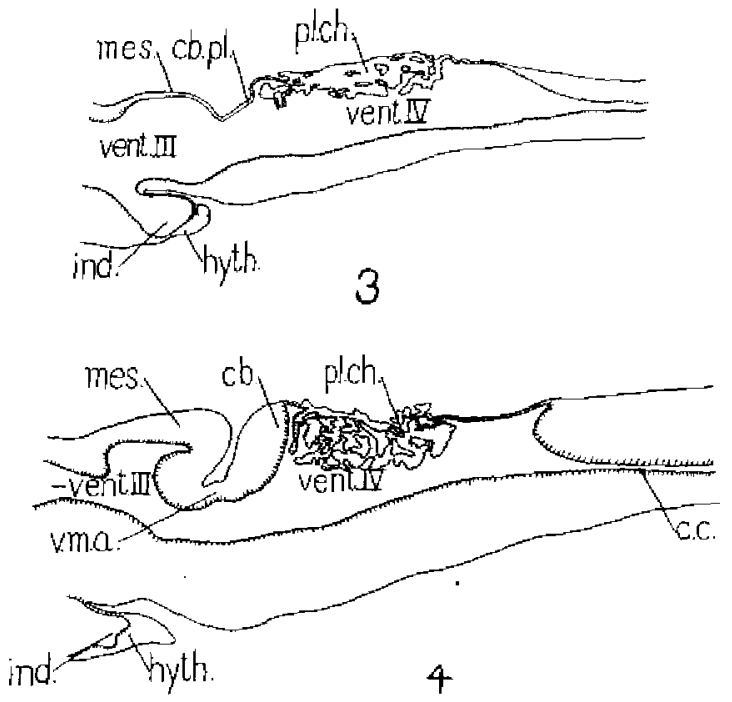

Fig. 3 Longitudinal section in mid-sagittal plane of brain sten of 16-mm.total-length tadpole, showing membranous roof of. IV ventricle, and part of III ventricle. Cajal method. Camera lucida. $\times 24$,

Fig. 4 Longitudinal seetion through nid-sagittal plane of tadpole with welldeveloped legs and with $12-\mathrm{mm}$. tail, showing the massive cerebellar structure in the mid-plane at this stage. Cajal method. Camera lueida. $\times 24$.

found the eminentia trigemini (figs. 1 and 2, em.V) as in urodeles (Herrick, '14).

Lateral to the ventral eminence and the corpus cerebelli, the recessus Iateralis continues forward as the anterior diverticulum (figs. 1, 2, 7, 9, 10, d.a.). In the 18-mm. stage this is bounded laterally and rostrally, as well as dorsally, by a thin membranous covering. Rostro-medially it is bounded by the ventral eminence and the anlage of the corpus cerebelli. The lateral wall of the recess is also membranous, 
but the caudal boundary becomes massive, due to the presence of the lateral-line lobe and the area acustico-lateralis (area statica of Kappers). The floor of the lateral recess thus forms a depression between the lobus lineae lateralis caudolaterally and the corpus cerebelli and eminentia ventralis

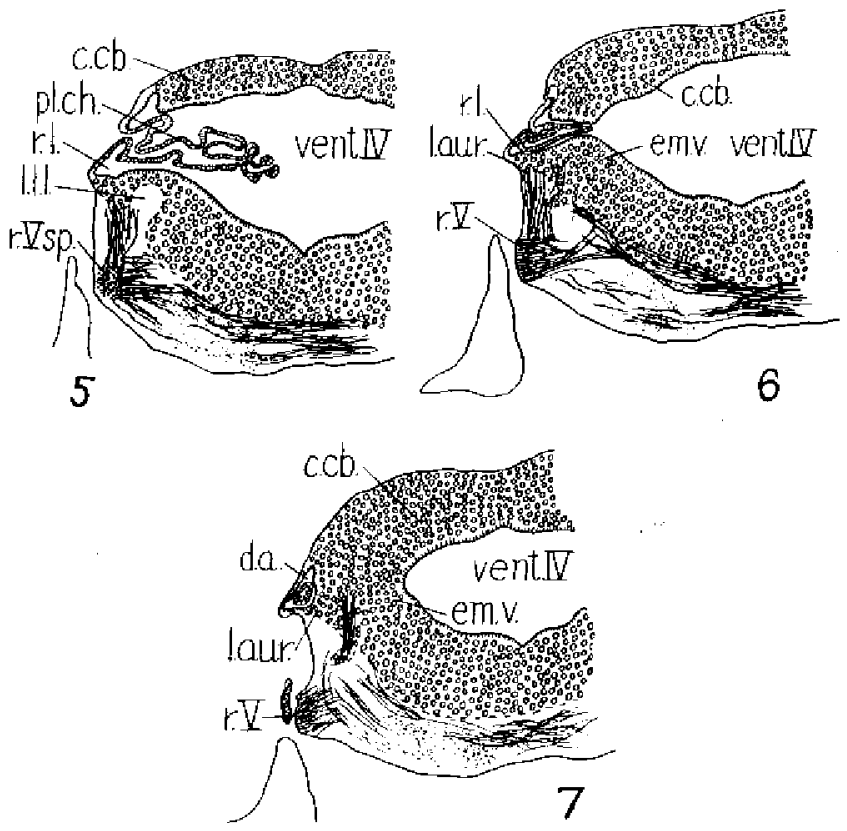

Fig. 5 Outine of section just eaudal to $\gamma$ root. Hyla regilla $28-\mathrm{mm}$, larva total length. Cajal method. Camera lucida. $\times 43$.

Fig. 6 Outline of section at caudal level of $V$ root. Hyla regilla, $28 \mathrm{~mm}$. total length. Cajal method. Camera lucida. $\times 43$.

Fig. 7 Outline of section near rostralmost level of $r$ root. Hyla regilla, $28 \mathrm{~mm}$. total length. Cajal method. Camera lueida. $\times 43$.

rostrally (figs. 1 and 2). This is more prominent in the 25mm. larva (fig, 2), in which the corpus cerebelli and eminentia ventralis are larger, and in which the lateral-line lobe has extended farther forward. Lateral to the anterior diverticulum there is a projection, the auricular lobe, which is continuous with the lateral-line lobe. 'The connection between the auricular lobe and the corpus cerebelli, while thin, is 
made up of nervous material. At this stage, therefore, the boundaries of the anterior diverticulum are massive. In a larva of $36 \mathrm{~mm}$. (figs. 9 and 10) the lateral-line lobe is quite prominent and the auricular lobe is connected with the corpus
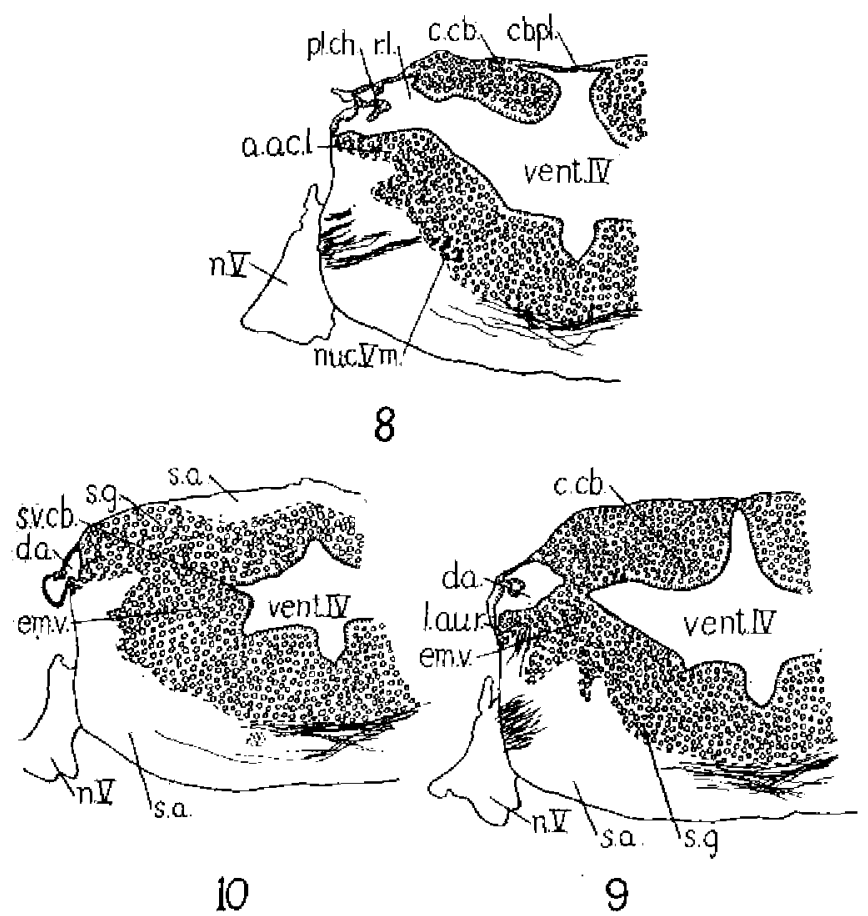

Fig. 8 Outline of section at caudal level of $V$ root from $H_{y l a}$ regilla of $36 \mathrm{~mm}$. total length with small hind legs. Vom Rath method. Camera lueida. $\times 43$.

Fig. 9 Outline of section about midway between rostral and caudal levels of $\checkmark$ root in Hyla regilla larva of $36 \mathrm{~mm}$. total length with small hind legs. Vom Fath method. Camera Iueida. $\times 43$.

Fig. 10 Outline of section at rostral level of $\mathrm{V}$ root in Hyla regilla larva of $36 \mathrm{~mm}$. total length, with small hind legs. Vom Rath mothod. Camera lueida. $\times 43$.

cerebelli by a thick mass which is continuous with the tegmental gray. Ineluded within this mass, however, are nerve fibers also. The anterior diverticulum is reduced in proportion to the thickness of this mass, i.e., the chief accretion of cells has been in the rostral wall of the diverticulum. 
Continnous with the auricular lobe caudally there is a mass of cells corresponding to the eminentia granularis of fishes, which merges with the lateral-line lobe. The area acustica is still separated from the corpus cerebelli and the eminentia ventralis by the depression which forms the floor of the lateral recess. This depression is relatively narrower than in earlier stages. The massive structures on either side of this furrow represent the two anlagen of the definitive cerebellum, as Herrick ('24) has recently shown. The two stages of tadpole last described, namely, the $25-\mathrm{mm}$.- and the 36 mm.-total-length larvae, represent in the development of the cerebellum, respectively, an early and an advanced stage of the process of fusion of the two components of the cerebellum. The cerebellum of Necturus, described by Herrick ('14), represents a stage between these two larval cerebella, as does also that of Amblystoma, as described by the writer ('20). Necturus shows an external morphology somewhat more advanced than the 25-mm. Hyla, while the cerebellum of Amblystoma is not so far developed as that of the $36-\mathrm{mm}$. Hyla.

In the adult frog (Rana) the corpus cerebelli has become so massive as to nearly obliterate the zone of fusion between it and the auricular lobe. The latter has also become reduced in size, due to the dropping out of the lateral-line system, but the relations of eminentia granularis, lobus aurieularis, and corpus cerebelli still remain and may be recognized from the internal strueture, as will be indicated subsequently.

Medially, as is well known, the two corpora cerebelli are connected only by a membrane in early stages of development (fig. 3). This is true of the $16-\mathrm{mm}$. Hyla for the entire covering between the anlage of the cerebellar bodies. In the 25mm. stage the thin portion of the covering has been narrowed so as to form the roof of only that portion of the fossa which lies approximately between the sagittal levels represented by the sulcus limitans on either side (fig. 2, s.l.). In the 36-mm. larva the cerebellum is massive across the mid-line also, although not yet developed to the condition of nearly equal 
thickness with the lateral portions, as in the adult frog. This condition is reached in Hyla by the 12-mm. tail stage (fig. 4).

The cerebellum is thus seen to be derived from two moieties on either side, namely, the auricular lobes and the corpora cerebelli, which fuse in the mid-plane to form the massive arch over the rostral end of the rhomboid fossa. The corpora cerebelli are formed by the pushing upward of the rostral region of the tegmentum bulbi just caudal to the isthmus, and represent the region, as Herrick ("24) has pointed out, in which the spino-cerebellar fibers and the tracts from the midbrain meet, in later stages of development. The auricular lobes are formed by a forward continuation of the lateralline lobes and receive the lateral-line and vestibular fibers. In addition to these principal groups, certain other fibers pass into the median portion, as will be set forth more fully in the section pertaining to the fiber tracts.

A continuation of the development noted in the 25- and 36mm. stages is seen in tadpoles after the legs have appeared and the tail has begun to be resorbed. The floor of the Iateral recess gradually fills up by an increase in thickness of the underlying tegmentum, nearly obliterating the depression between the area acustica and the ventral cerebellar eminence. The latter fuses with the corpus cerebelli laterally and nearly disappears as a separate swelling, except for a small remnant. at the point where the cerebellum begins its arch over the rostral end of the fossa.

This fusion of the body of the cerebellum and the ventral eminence results in forming a massive median wall for the anterior diverticulum (figs. 6, 7, 9, and 10). By the $36-\mathrm{mm}$. stage the median half of the dorsal roof has also become massive caudally (fig. 9). Rostrally the diverticulum is continued into a blind membranous pouch, around the median wall of which the stratum griseum reaches the surface of the cerebellum (figs. 9 and 10). This represents the region of fusion of the auricular lobe with the ventral eminence and the body of the cerebellum. 
The corpus cerebelli increases rapidly in size and differentiation. Its early condition of a slight thickening which rolls upward, as described, at the latero-rostral end of the floor of the fossa in the 16-to-18-mm. stage is soon converted into a relatively massive structure. In the tadpole of $25-\mathrm{mm}$. it has extended dorsally so as to present a nearly vertical wall (fig. 2) of considorable thickness and height at the rostral boundary of the lateral portion of the fossa. Laterally this wall becomes lower and also thinner and curves gently forward until it reaches its extremity at the anterior diverticulum of the lateral recess. Medially it curves forward more abruptly to become continuous with the lateral wall of the aqueduct, and with the still membranous median portion of the cerebellar arch.

A thin continuation from the dorsalmost edge of the corpus cerebelli connects caudally with the chorioid plexus of the IV ventricle. This is regarded as the homologue of the velum posterius.

The eminentia ventralis in the $25-\mathrm{mm}$. stage has to a large extent fused with the corpus cerebelli laterally. The acoustie area and the auricular lobe are still separated from it by the floor of the lateral recess.

As the mass of the corpus cerebelli increases in volume with further growth, it extends caudally as a pronounced rounded protuberance into the fossa. The nearly perpendicular wall of the $25-\mathrm{mm}$. larva gives place by the $36-\mathrm{mm}$. stage to an overhanging wall, toward which slopes upward from below the eminentia ventralis, except in the Iateral recess. Rostral to this recess the wall is still relatively thin, but nevertheless massive, in the $36-\mathrm{mm}$. tadpole.

The corpus cerebelli has also grown medially so that the thickest part of it, in the rostro-caudal direction, lies a short distance Iateral to the median line. The membranous median roof of the earlier stages, as already indicated, has given place to massive structure, although relatively thin, as compared with the region more lateral. 
At this stage the acoustic area is prominent and is separated from the corpus cerebelli and the eminentia ventralis by a rather narrow furrow-the hollowed floor of the recessus lateralis. The development of the acoustic area has resulted in a definite marking of the lateral wall of the medulla oblongata into a slightly rounded swelling, visible externally, which continues forward from the level of the VII and VIII root complex to the auricular lobe (figs. 15 and 24, em.gr.). This is cellular, and appears to correspond with the eminentia granularis of fishes. Rostrally the acoustic area and the auricular lobe are now continuous with the body of the cerebellum, and medially, under the floor of the lateral recess, they are continuotus with the ventral eminence.

\section{HISTOLOGICAL PATTERN}

A comparison of Cajal and hematoxylin series of larvae at different stages of development, supplemented by Golgi series of stages from $28 \mathrm{~mm}$. total length and upward, shows different patterns of histological structure which vary with the age of the tadpole. The younger stages were refractory to the Golgi method, but Cajal series were quite satisfactory and showed many details of structure in these younger stages very well.

The rostral portion of the medulla oblongata in the 16 - to $18-\mathrm{mm}$. tadpole is very simple in pattern. Two well-defined layers, a stratum album and a stratum griseum, are present. These are derived, respectively, from the marginal laycr and the mantle layer of the early embryonic nerve cord. In a $16-\mathrm{mm}$. larva a section at the caudal level of the $V$ root (fig. 12) shows the simple arrangement of the two layers. Above this level is located the widest part of the recessus lateralis, just in front of which occur the modifications of the rostral part of the primitive oblongata which result in the development of the cerebellum. But little differentiation of the gray substance has occurred up to the $16-\mathrm{mm}$. stage. The principal differentiation of cells apparent in Cajal preparations is found in the development of the motor $V$ nucleus (figs. 12 
and 13, mor. $Y . m$.$) . These cells are larger than those of the$ surrounding tegmentum and have well-defined processes. Their axones form the motor $V$ root, while some of their
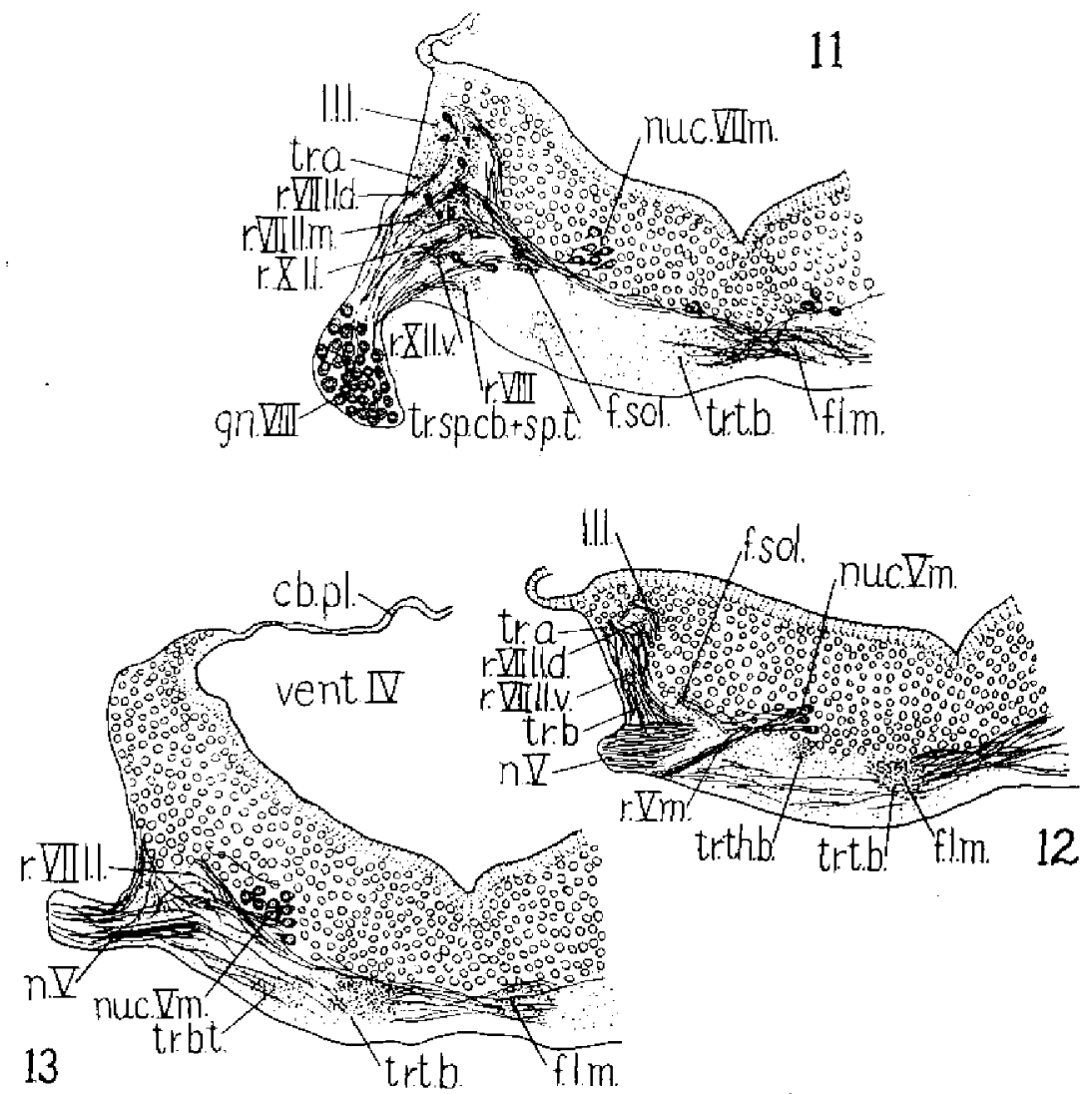

Fig. 11 Section at level of literal-line VII roots in Hyla. regilla larva of $16 \mathrm{~mm}$. total length, with no legs. Cajal method. Camera lueida. $\times 94$.

Fig. 12 Section at eaudal level of $\mathrm{V}$ roots in Hyla regilla larva of $16 \mathrm{~mm}$. tota length. Cajal method. Camera lueida. $\times 94$.

Fig. 13 Section at rostral level of $\mathrm{V}$ roots in Hyla regilla larva of $16 \mathrm{~mm}$. total length. Cajal methorl. Camera lueida. $\times 94$.

dendritic processes extend laterally and caudally, coming into relation with the spinal $\mathrm{V}$ and spino-tectal tracts.

The floor of this part of the recess shows a slight swelling, the foreshadowing of the eminentia trigemini. The tegmental 
griseum cxtends laterally to the external surface of the oblongata, dorsally, but ventrally a layer of nerve fibers intervenes between this and the surface.

The stratum album continues forward from the oblongata to the cerebellar folds. Here it covers the lateral portion of the stratum griseum with a thin layer in early stages (fig. 14). By the 18-mm. stage a portion of it, as seen in transverse scetion, has been nearly separated from the main mass of the alba by a lateral extension of the stratum griseum. It remains continuous, however, around this mass of griseum with the alba of the oblongata, caudally, and rostrally be-

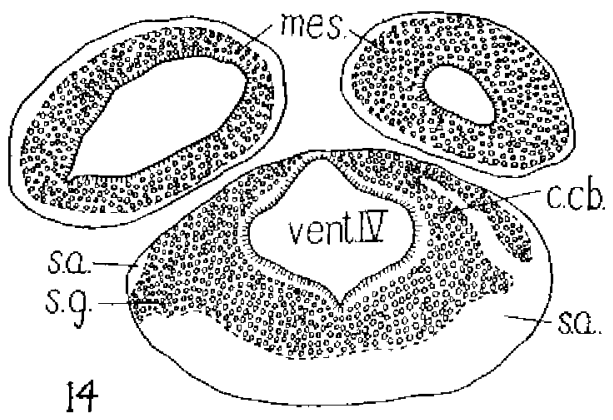

Fig. 14 Outline of section just rostral to level of $V$ roots in Hyla regilla of 16 mm. total length, slowing relation of the stratum album and stratum grisenm of the cerebellum to the eorresponding layers of the medalla oblomgata. Caja! method. Canera lueida. $\times 63$.

comes the alba of the cerebellar folds. In this region it is increased in thickness, and in later stages becomes differentiated into the molecular layer of the cerebellum (stratum album of Hexrick, '14). This layer of the cerebellum must therefore be regarded as a modified and isolated portion of the white layer of the medulla oblongata.

The dorsal portion of the layer of alba which intervenes between the greater part of the griseum and the surface of the oblongata at this level is made up of very delicate fibers, with some coarse ones. It receives the lateral-line tracts and corresponds to the dorsal island of alba of Kingsbury ('95), which Norris ('08, '13) and Herrick ('14 a) have com- 
pared with the lobus lineae lateralis. It is composed of a mass of neuropil, with some cells, and extends into the auricular lobe, as already stated. Its correspondence to the lateral-line lobe is substantiated by the fact that it disappears with the degeneration of the lateral-line systems in the frog.

The stratum gristum contimus laterally and dorsally from the rostral level of the radix trigemini in a broad dorsomedially curving band (fig. 13). The dorsalmost portion forms the anlage of the corpus cerebelli. At the caudal level of the $V$ root there is an invasion of the gray mass by fiber tracts from the lateral-line VII roots and also by trigeminal fibers. At the level of the VII-VIII roots the tegmental gray is shallower than more rostrally. Furthermore, it does not reach the lateral surface of the oblongata in this region (fig. 11), due to the large expansion of the lateral-line area already noted. The dorso-medially curving mass in front of the $\mathrm{V}$ root (fig. 13) shows no differentiation of cells at this stage, beyond the condition represented by the tegmental cells of the oblongata.

The stratum album at this level continues but a little distance dorsal to the $V$ root, so that the griseum reaches the external surface of the bulb. It thus forms not only the floor of the ventricle, but also the lateral surface of the oblongata at this level. Some fibers from the trigeminal root form a thin layer outside the ventralmost part of this mass which represents the anlage of the corpus cerebelli.

The vestibular nucleus is represented in an incipient state by a group of differentiated cells at the entrance of the ventral VIII root, which Kappers ('20) has shown is the vestibular root in the frog. Somewhat smaller cells are also present in the lateral-line area.

The changes which take place in the development to the 28 mm. stage are illustrated in figures 15 and 16 , which were drawn from sections taken at approximately the same levels as the preceding. It will be noted that in the $28-\mathrm{mm}$. larva the body of the cerebellum has enlarged and tilted caudally to 
such an extent that its dorsal part arches over the level of the plane which passes through the trigeminal roots. Ventrolaterally it is connected with the oblongata by the tela chorioidea, which invaginates into the lateral recess with the chorioid plexus. Above, a portion of the anterior diverticulum of the lateral recess is bounded medially and ventrally by the massive cerebellar body and laterally by membrane. In the oblongata the 'dorsal island' or lateral-line lobe has erowded upward so as to lie directly against the ependymal layer dorsally, but scattered cells of the tegmentum continue to the lateral surface of the bulb ventral to the lateral-line lobe. Within the latter may be recognized the dorsal, medial, and ventral rami of the lateral line VII nerve (figs. 15 and 16, r.VII l.l.d., l.l.m., and l.l.v.). The eminentia trigemini is more prominent and the fiber tracts are better developed than in the preceding stage described.

Corresponding levels of the 28-mm. larva, as compared with that of $16-\mathrm{mm}$., show a greater elaboration of fiber tracts and a larger size and more complete differentiation of the cells. Comparison of sections at the caudal level of the $V$ root in the $16-\mathrm{mm}$. and the $28-\mathrm{mm}$. larvae (figs. 12 and 16) shows that the major features are much alike, but there are modifications of detail. It will be noted that the lateral-line lobe in the 28-mm. stage is more dorsally located. A few small cells, resembling those of the stratum griseum, separate it from the lateral surface of the oblongata, and scattered cells extend ventrally between this surface and the fiber tracts leading to the 'dorsal island.' The entire mass of the oblongata, at this level, is much thickened, as compared with the younger stage, and is less flattened out. The corpus cerebelli has grown both medially and caudally so as to arch over the fossa. It has fused with its fellow of the opposite side and is massive even across the mid-line (fig. 16). There is also to be noted a more pronounced differentiation of the cerebellar strueture laterally into stratum griseum and stratum album. The recessus lateralis extends beyond the lateral border of the cerebellum so that the roof of its most lateral portion 

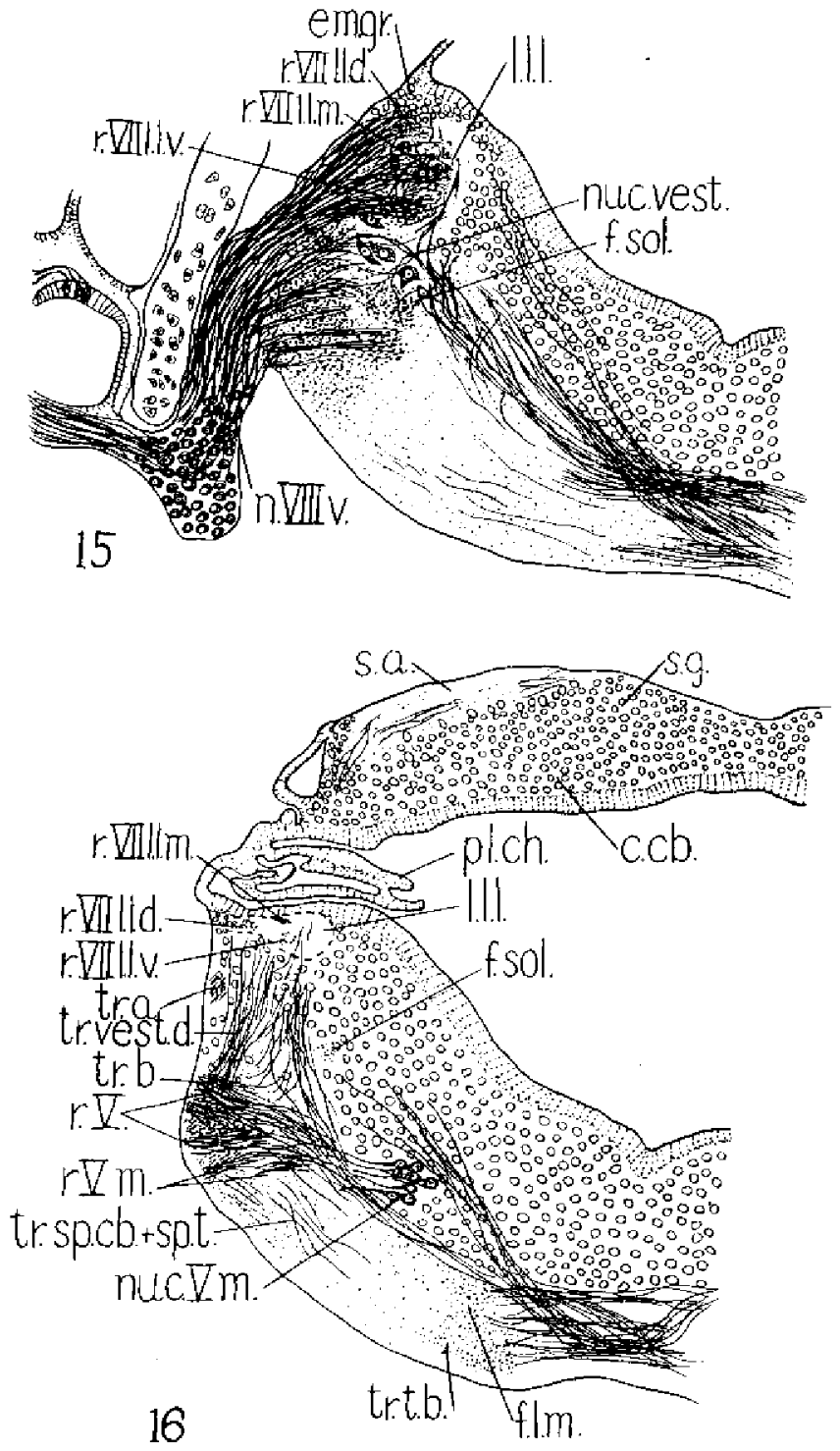

Fig. 15 Section at level of laferal-line VII root in Hyla regilla of $28 \mathrm{~mm}$. total length, with no legs. Cajal method. Camera heida. $\times 94$.

Fig. 16 Seetion at andal level of $V$ root in Hyla regilla of $28 \mathrm{~mm}$. total lengtl, Cajal method. Camera lueida. $\times 94$.

THF JOCRNAL OF COAPARATLE NEURGAGY, VOL. 39, No 2 
is membranous, with folds of the chorioid plexus extending into the recess. There is also a marked invasion of the outer zone of the oblongata at this level by nerve fibers, derived in part from the trigeminus and in part from othen sources. Some undifferentiated cells are still present, but there are enough fibers to give a distinct layer of white substance.

By the 28-mm. stage also the tegmental mass has been divided laterally into a lateral and medial part by the 'dor'sal island.' The lateral mass lies in the dorso-lateral angle of the oblongata. It is conneoted with the main median mass by a continuation of cells one or two layers deep above the alba. At the level of the VII root some of the fibers of the dorsal lateral-line VII root terminate among its cells. The cellular mass becomes thin between the 'dorsal island' and the lateral surface of the oblongata at the level of the VII roots, but caudal to this it contimues again as far as the $X$ roots, although attenuated. Rostrally this cell mass continues into the auricular lobe and rostro-medially into the griseal layer of the cerebellum and the tegmentum.

The lateral-line VII tracts may be traced forward within the 'dorsal island,' in silver preparations, toward the auricular lobe. Dorsal, medial, and ventral tracts may be recognized. Their fibers are coarse in contrast with the very delicate fibers which form the greater part of the lateral-line lobe. Near the rostral end the coarse lateral-line fibers disappear, apparently by subdivision into more delicate fibers, and the 'dorsal island' tapers toward the auricular lobe, in which it also disappears.

Due to the forward elongation of this region of the bulb, the massive dorsal extension of the tegmentum, seen at the level of the $V$ roots in the $16-\mathrm{mm}$. larva, has in the $28-\mathrm{mm}$. stage been pushed forward, and the lateral wall of the rhomboid fossa above this is membranous.

In the region of the lateral-line VII roots, Cajal sections show the 'dorsal island' as a large area into which the lateralline roots pass (fig, 15, l.l.l.). A few cells, larger and more differentiated than the tegmental cells, are present at the 
point of entrance of these roots. Golgi sections show that synaptic connections are present between these cells and the lateral-line fibers (fig. 17), Their axones form internal arcuate fibers (figs. 15 and 17) which pass to the lateral lemniseus. This group of cells, which was also noted in the 16 -mm. stage, must be regarded as constituting a lateral-line nucleus which corresponds to the lobus lineae lateralis of fish brains and the nucleus dorsalis of .Johnston ('02) in Petromyzon.

At the entrance of the vestibular nerve (fig. 15) the group of cells noted in the $16-\mathrm{mm}$. larva, and designated as the vestibular nucleus, have increased in size and number. The cell mass extends rostrally into the ventral cerebellar eminence, where it is continuous with the anlage of the nucleus cerebelli, as shown in figures 18,19 , and 30 . As seen in transverse sections, this mass of cells is located laterally, somewhat away from the general tegmentum. Dorsally it is bounded by the lateral-line VII roots and ventrally by the substantia alba. Medially it is continuous with the tegmentum.

At 28-mm. and other early stages there is little by which the vestibular nucleus can be distinguished from the nucleus cerebelli, except its more caudal position. Even in late stages there is no sharp line of demarcation between them. There is a difference in size of cells in the late stages in the rostral part of the nucleus cerebelli as contrasted with the remainder of this nucleus and the vestibular nucleus (fig. 17), but the two mnclei merge into each other. The axones from the rostral cells of the nucleus cerebelli pass forward and medially to form the brachium conjunctivum. The axones from the more caudal cells of the cerebellar part of the nucleus pass to the tegmentum of the oblongata (figs. 19, 21, 31, and 32) to form internal arcuate fibers, some of which are collected together into a cerebello-tegmental tract (figs. 19 and 29, tr.cb.teg.b.) in the older stages.

The cells of the caudal portion of the combined nucleus are of smaller size. It is this region which develops into the vestibular nucleus. The dendritic branches of these cells pass 


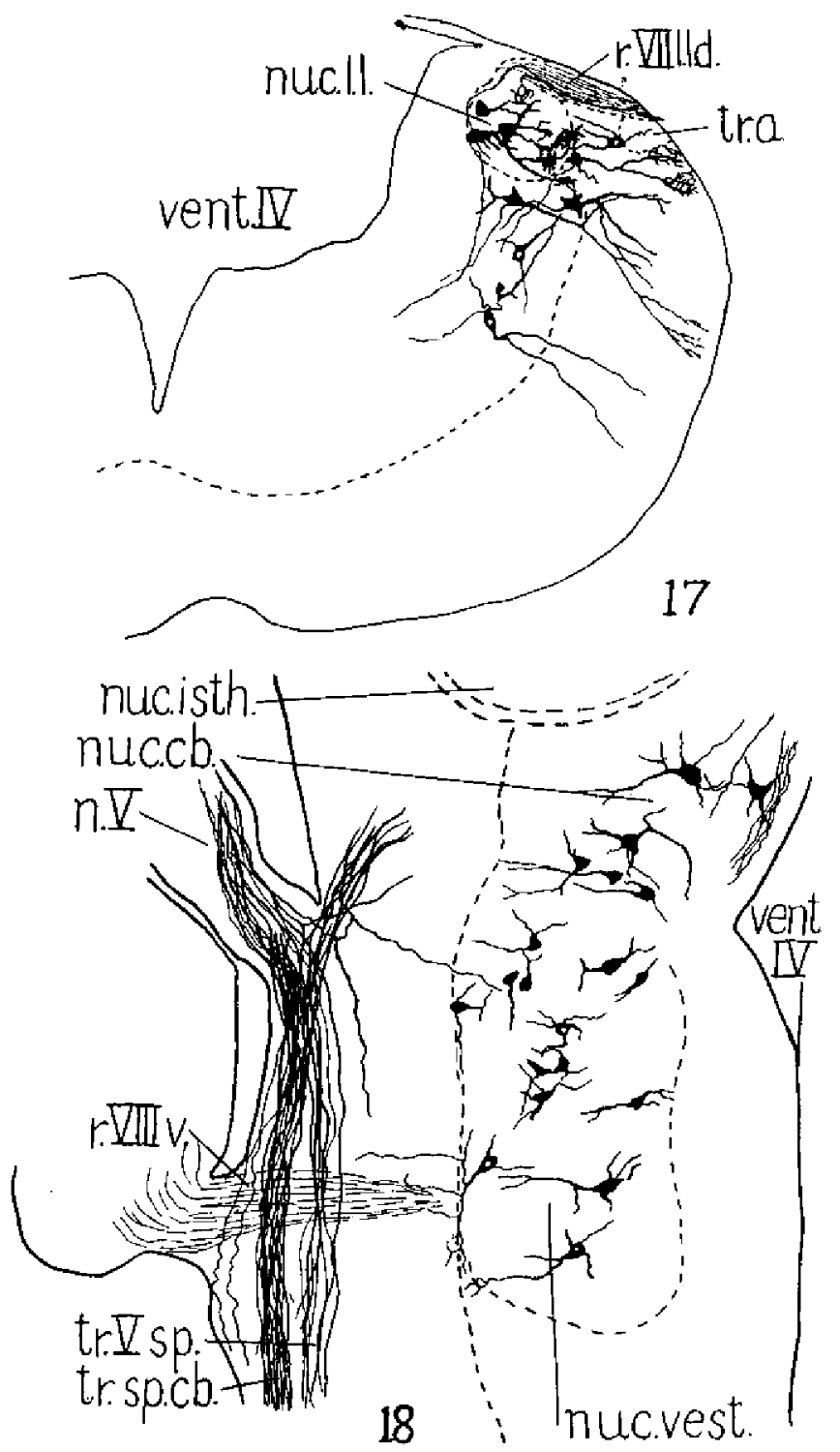

Fig. 17 Transwerse section at entrance of lateral-line VII roots, showing syuntic connections of its fibers with cells of the lateral-line lobe. Ifyla regilla of $44 \mathrm{~mm}$. total length, with small hind legs and no fore legs. Golgi method. Cscmera lueida. $\times 94$.

Fig. 18 Horizontal seetion, showing rostral region of medulla oblongata with nueleus cerebelli and nucleus vestibularis in young frog of 1-mm. tail length. Hyla regilla. Golgi method. Camera lueida. $\times 94$. 
in large part lateralward and break up into processes which are distributed among the entering fibers of the vestibular nucleus (fig. 18). Their axones cross as internal arcuate fibers to the opposite side. The details of their distribution have not been worked out, but are no doubt similar to other forms.

Golgi sections reveal an interesting arrangement of the cell processes and cell groups in stages in which these are

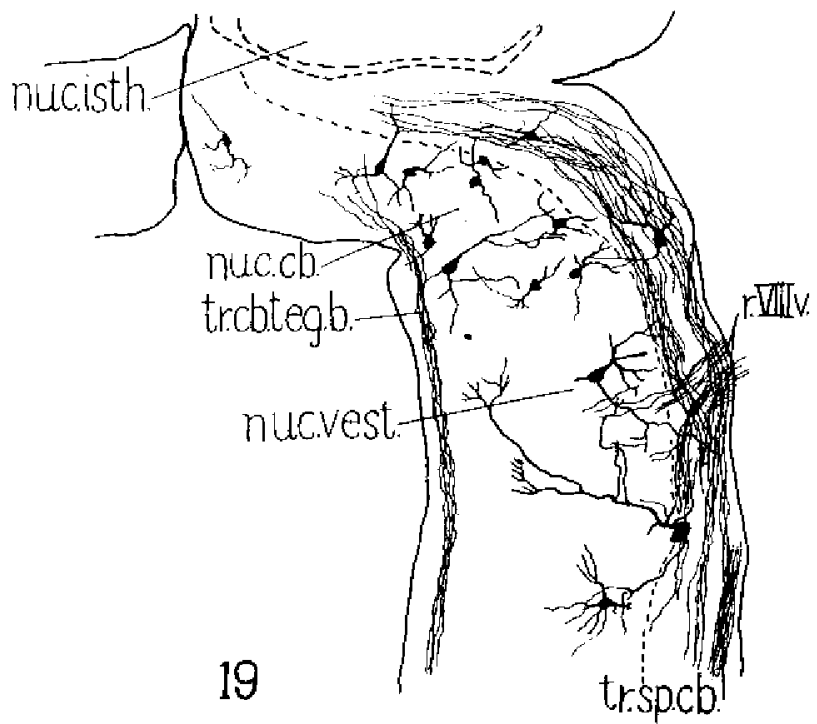

Fig. 19 Iorizontal section through rostral region of medulla oblongata at more dorsal level than preceding figure. IIyla regilla of 1-mm. tail length. Golgi method. Camera lucida. $\times 80$.

differentiated. Most of the cells send their dendritic processes into the stratum album of the oblongata. Here they branch out into dendrites which come into relationship with one or more fiber tracts, so that there is repeated in the frog larva the condition described in Amblystoma by Herrick ('14 a). This is apparent in the younger stages which took the Golgi impregnation; that is, in larvae of 28 to $33 \mathrm{~mm}$. total length, in which the hind legs were of small size and the fore legs had not yet appeared cxternally. It continues, however, to 
some extent in later stages also in the region of the ventral cerebellar eminence, and is found in the adult frog at this level, as is shown in figure $t$ of the writer's account of the adult cerebellum in the frog ('23).

The axones of these cells pass ventrally and medially as internal arcuate fibers. In the region of the vent ral cerebellar eminence some are direeted forward, as already indicated, to form the brachium conjunetivum, while others which arise from cells in the corpus cerebelli and the ventral emineree pass caudally close to the floor of the ventricle as the eerebello-tegmental tract.

In the transition zone between the oblongata and the ventral eminence there are various gradations from cells with widespread dendritic processes into the alba (fig. 20), as described, to cells whose dendrites apparently do not reach beyond the limits of the nucleus cerebelli (figs. 20 and 21). In addition to the cells with long dendritic processes there are numerous smaller cells, especially in the later stages of metamorphosis. These have short processes, both dendrites and axones, and make up the great mass of the tegmental cels (figs. 22 and 23).

In the Hyla of $11-\mathrm{mm}$. tail length, witls well-developed legs (figs. 17 and 18), the eminentia ventralis forms a prominent rounded elevation in the fossa and the medial region of the fossa is much deeper than in preceding stages. The floor of the lateral recess now shows the sulcus lateralis, which is scarcely to be recognized in earlier larvae. This suleus marks the boundary between the trigeminal eminence and the acoustic area. In the floor of the latter the lobus lineae lateralis is discernible, but shows signs of disappearing this far rostrally. The lateral-line tracts, however, are still visible in transverse sections. There is a continuation of the tegmental cells above the lateral-line lobe to the lateral surface of the oblorgata, as ir earlier stages, and cells of similar appearance are also intermingled to some extent among the fibers. Just before completion of development, in specimens with a tail stump but $1 \mathrm{~mm}$. in length, the lateral- 
line tracts have completely disappeared at the level of the $\mathrm{V}$ roots, as elsewhere. The lateral-line lobe has become continuous with the white substance of the ventral part of the oblongata. The tegmental cells, however, as previously noted, continue to the lateral surface in the floor of the lateral recess.
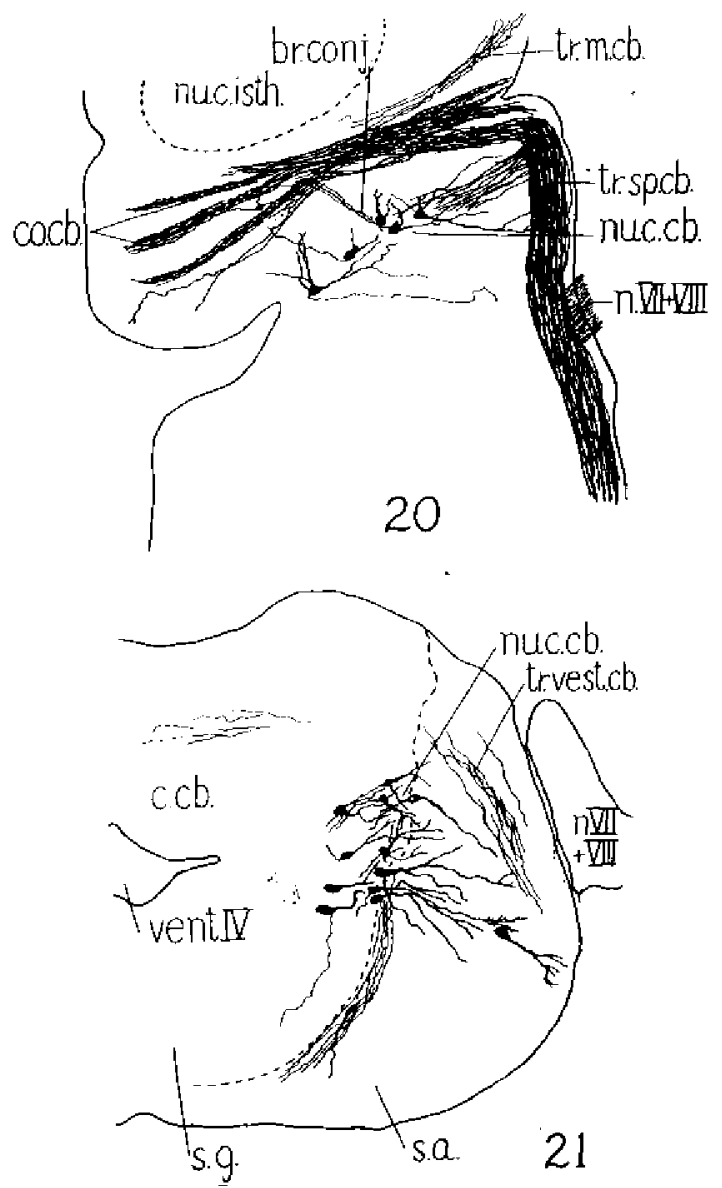

Fig. 20 Horizontal aeetion through nucleus cerebelli, showing brachium conjunctivum and collaterals from spino-cerebellar tract. Hyla regilla of $20-\mathrm{mm}$. tail length ( $32 \mathrm{~mm}$. total length) with well-developed hind legs and medium-size fore legs. Golgi method, Camera lucida, $\times 63$.

Fig. 21 Transverse section through rostral end of medulla oblongata and cercbellum, showing caudal part of nuclens cerebelli. Hyla regilla of $30-\mathrm{mm}$. total length," with small hind legs and no fore legs. Golgi method. Camera lucida. $\times 63$. 
Turning attention now to the region of the VII and VIII. roots, it is to be recalled that in the $16-\mathrm{mm}$. stage the 'dorsal island' or lateral-line lobe forms a large rounded area, as

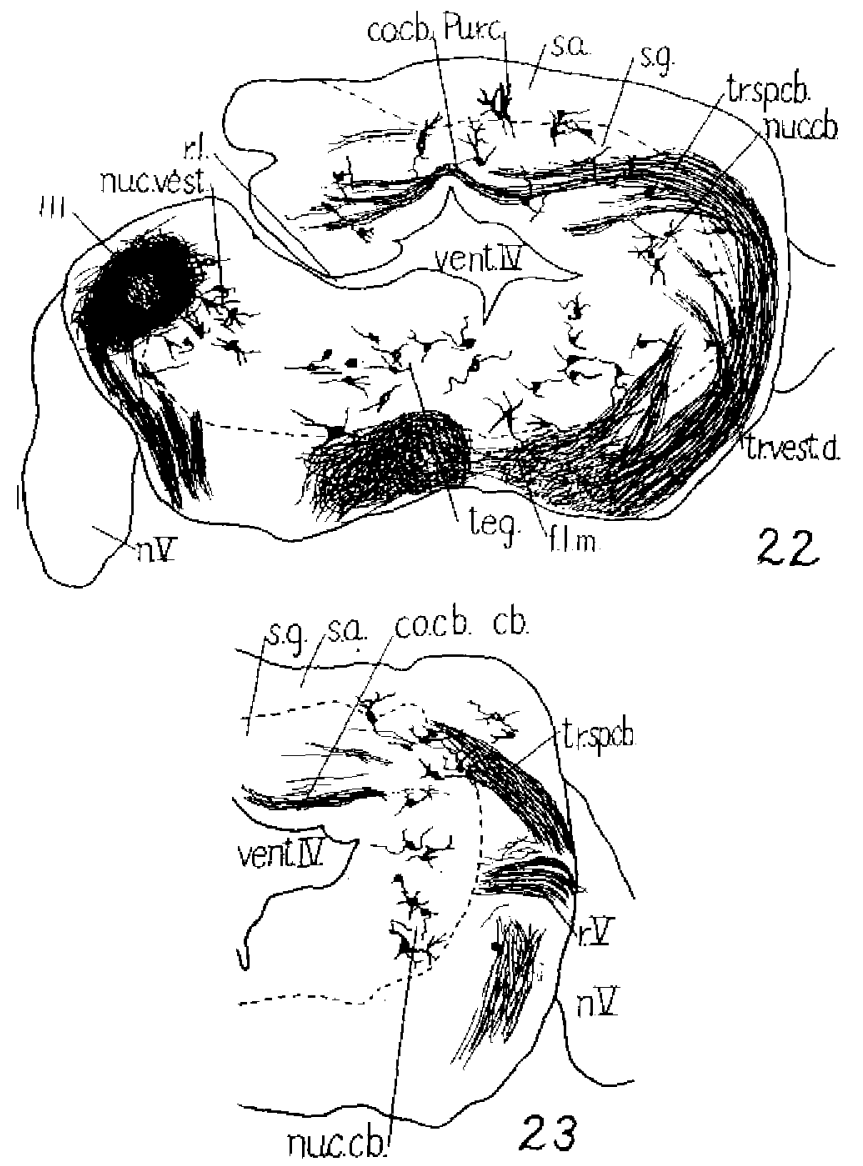

Fig. 22 Transverse seetion through rostral end of medulla oblongata and cerebellum of iarva of $42-\mathrm{mm}$. total length, with small hind legs and no fore legs. Golgi method. Camera lucida. $\times 51$.

Fig. 23 Transwerse section at rostral level of $V$ root in larva of 42 -mm. total length, with small hind legs and no fore legs, Golgi method. Camera lucida. $\times 51$.

seen in transverse section. The dorsal and medial lateral-line roots of the VII enter the lobe directly (fig. 11), the medial root entering at the extreme ventro-medial border of the lobe. 
In $\Lambda$ mblystoma larvae (Herrick, ' 14 a) only the dorsal lateralline VII root enter's the lobe, although in adilt Amblystoma it receives fiber bundles from middle and ventral lateral-line VII roots also. The frog tadpole, therefore, more nearly resembles the adult Amblystoma even at this early stage, in this respect, than it does the larval salamander. A distinct. vestibular root enters ventral to the lateral-line roots and terminates among a group of small cells which represent the incipient vestibular nuclens.

In the lateral-line lobe, nerve cells may also be recognized at this level in the $16-\mathrm{mm}$. larva. These are of smaller size than the cells of the more ventrally placed vestibular nucleus. Dorsal to the lateral-line region a thin layer of undifferentiated cells of the tegmentum reaches to the lateral surface, passing between the ependymal layer and the 'dorsal island.'

At $28 \mathrm{~mm}$. dorsal, medial, and ventral lateral-line roots enter the lateral-line lobe directly (fig. 15). The area is very prominent in cross-section at this stage, and produces a slight swelling on the lateral surface of the oblongata, above the entranee of the VII and VIII roots. This swelling extends rostrally to the auricular lobe and evidently corresponds to the eminentia granularis of fishes.

In the 11-mm. tail stage the lateral-line area, as seen in transverse section, is strongly demareated at the VII and VIII root level (fig. 24), but is limited in extent. Dorsal, medial, and ventral lateral-line VII roots enter it, and their fibers at this stage are much coarser than in earlier larvae. These roots can be traced forward to the auricular lobe as dorsal, medial, and ventral bundles, respectively. A few nerve cells are included within the area, but these are of small size. The cells of the more ventrally located vestibular nucleus have, however, greatly increased in size, as shown in the figure, and their axones form a prominent bundle of internal arcuate fibers which cross the midline and ascend in the lateral lemmiseus. From the $11-\mathrm{mm}$. tail stage and on, the lateral-line VII nerve, together with the corresponding branches of the $X$, undergo progressive degeneration, and 
the lateral-line lobe decreases in size, to eventually disappear just before metamorphosis is complete.

In the young frog of $1-\mathrm{mm}$. tail (figs. 26 and 27 ) there is recognizable distinctly a dorsal and a ventral VIII nerve,
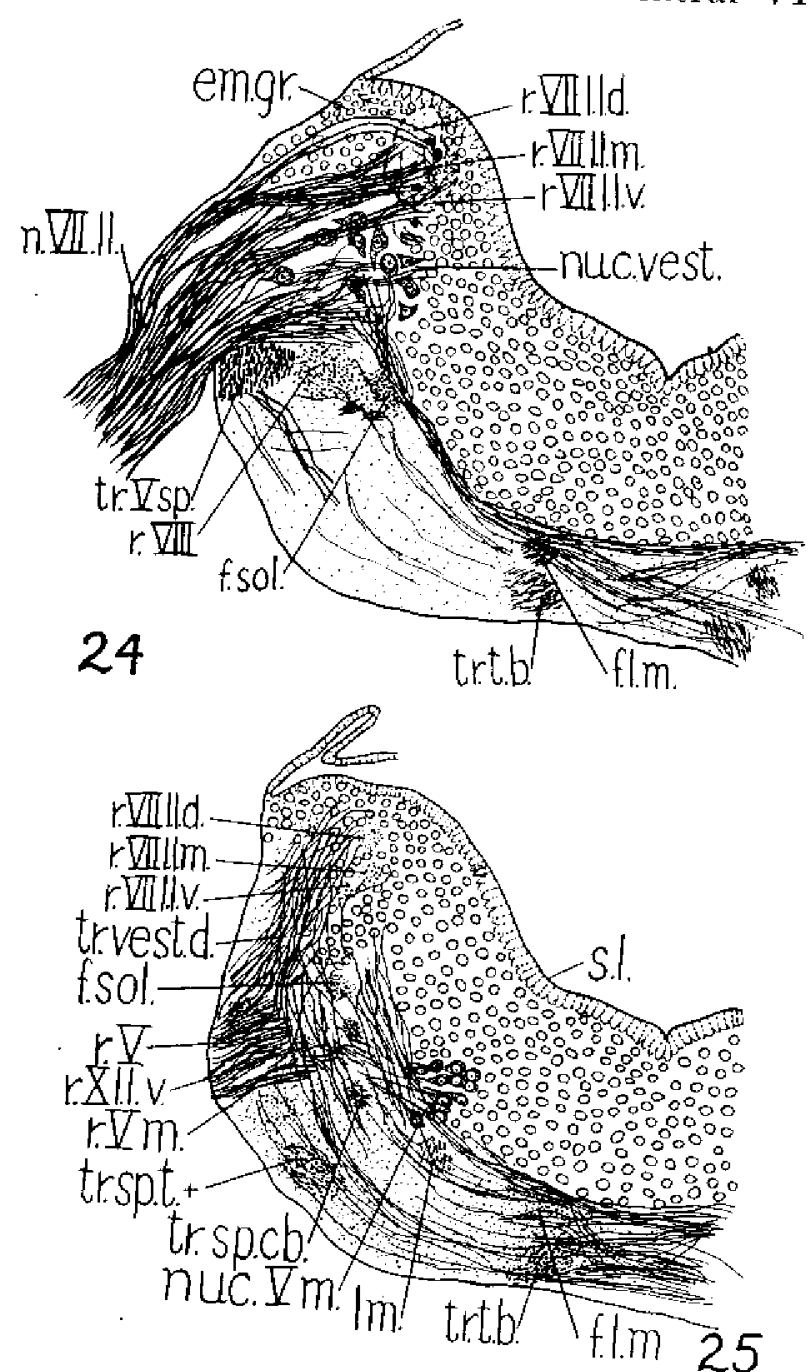

Fig. 24 Seetion at level of lateral-line VII roots in Hyla regilla of 11-mm. tail length, with well-developed legs. Cajal method. Camera lueida. $\times 94$.

Fig. 25 - Section at caudal level of $v$ root in Ifyla regilla of $11-\mathrm{mm}$, tril length, with well-developed legs. Cajal method. Camera lueida. $\times 94$. 
corresponding to the cochlear and vestibular nerves, as Kappers ('20) has pointed out in the adult bullfrog. In addition to the ventral restibular nucleus already noted, there is now present dorsally a large-celled nucleus in relation to the enter-

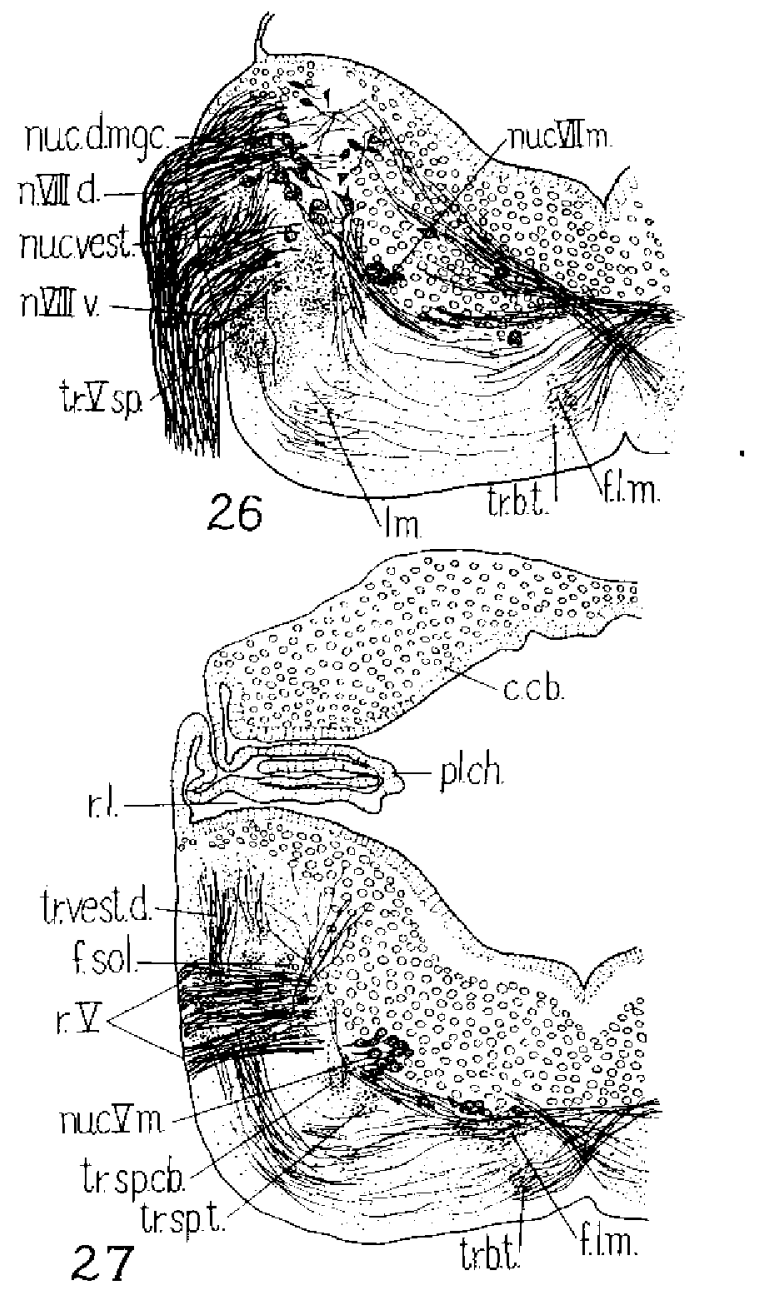

Fig. 26 Section at level of dorsal (eochlear) root of VIII nerve in young frog that has just completed metamorphosis. Hyla regilla of 1-mm. tail length. Cajal method. Camera lueida. $\times 63$.

Fig. 27 Section at caudal level of $V$ root in young frog of $1-m m$. tail length. Fyla regilla. Cajal method. Camera lueida. $\times 63$. 
ing roots of the dorsal or cochlear nerve. This nucleus Kappers calls in the bullf rog the nucleus magnocellularis, and it obviously corresponds to the combined cochlear nuclei of higher vertebrates. Placed dorsally and medially with respect to the large-celled nucleus are found a number of smaller cells, with some fibers, in the region occupied in earlier stages by the lateral-line lobe (fig. 26). The significance of these cells I have been unable to determine with certainty, but some appear to be in process of degeneration, and they probably represent the remnants of the cells found in earlier stages as part of the lateral-line connections.

The lateral-line tracts themselves have disappeared entirely, as figure 27 shows, rostral to the VII and VIIL roots. In the immediate vicinity of these roots and at their points of entrance into the oblongata there are present two tracts which correspond in position to the ventral and medial lateralline bundles, and which probably represent remnants of these tracts. I was not able, however, to determine their relationship with any degree of assurance.

In an effort to study the course of the disappearance of the lateral-line tracts, some twenty brains, representing various stages of metamorphosis from the initial phases to the fully developed frog, were prepared by the Marchi method and by the sodium-iodate modification of this method. No sign of degeneration of the wallerian type was observed at any stage, although well-stained silver preparations show the lateralline tracts to be absent in the young frog. The process by which these fibers disappear would be of interest, but the results obtained throw no light on the subject.

There appears to be considerable variation in the stage at which the lateral-line organs and their connections degenerate. The pit organs of the skin begin to disappear in the head region in tadpoles of about 10 - to $11-\mathrm{mm}$, tail length. In a large number of tadpoles examined with reference to the disappearance of the pit organs, it was found that the infraorbital line showed signs of degeneration, so far as such signs were visible by cxamination of the skin surface with a 
lens, at the stages indicated. In tadpoles of 5 -mm. tail length there remain only traces of the infraiorbital line of pit organs. At $3.5 \mathrm{~mm}$. tail length the supraorbital line was also represented only by traces, although the body and tail pits were still easily visible. Between this stage and that represented by a tail stump of $1-\mathrm{mm}$. length, all the pit organs had completely disappeared from both head and body regions. The distribution of the lines of pit organs in Hyla correspond quite elosely to the description given for the tadpole by Kingshury ('95).

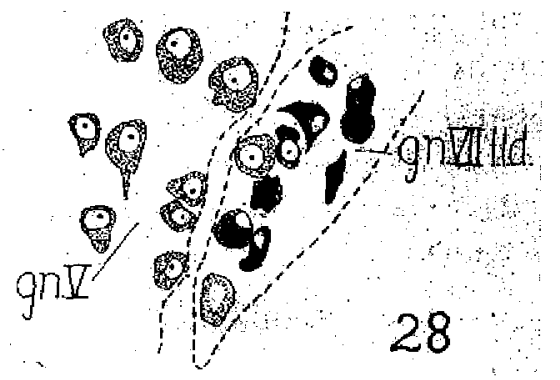

H'ig. 28 Portions of ganglia of the $\mathrm{V}$ nerve and of the lateral-line VII (dorsal VII root), showing chromalolysis of the cells in the latter which aecompanies degeneration of the lateral-line nerve. Hyla regilla of $3.5-\mathrm{mm}$, tail length. $N$ issl method. Camera lucida. $\times 256$.

Some slight changes in the lateral-line tracts, such as reduction in number of fibers and a decrease in the area of the 'dorsal island,' begin to appear at about the 12-mm. tail stage. Serial sections of the entire head region in specimens of 12-mm. tail, 3.5-mm. tail, and 1-mm. tail, stained by a modification of the Nissl method, show chromatolytic degeneration in the ganglion cells of the lateral-line VII nerve (VII b of Strong, '95), as shown in figure 28, and also some chromatolysis in the lateral-line portions of the IX and $X$ ganglia. The number of degenerated cells encountered was greater in the $3.5-\mathrm{mm}$. and $1 \mathrm{~mm}$. stages than in that of 12 mm., as was to have been expected. A thoroughgoing study of the various changes which occur in these ganglia during 
metamorphosis would be of great interest, but has not been attempted by the writer. Hyla does not provide favorable material for such a study, because of the fact that some of the cranial ganglia are so crowded together as to be very difficult to differentiate.

The chromatolytic changes observed are in process at the same time that the pit organs of the skin are disappearing, and are obviously due to the same cause, namely, the degeneration of the lateral-line nerves. As a result of this loss of the lateral-line system and its connections, the auricular lobe decreases progressively in size in later stages, as was pointed out by the writer in the previous communication. In the adult frog it is relatively quite small and receives only vestibular fibers. In the meantime it has fused across the floor of the recessus lateralis with the corpus cerebelli, as already described, so as to have become definitely a part of the cerebellar mass.

\section{NUCLEI}

Nucleus vestibularis and nucteus cerebelli. Reference has already been made to the genetic relationship of these two nuclei. They are also related functionally, as is shown by their connections (fig. 18). In the frog larva there is no differentiation apparent in the vestibular nucleus into the several parts found in more specialized forms, so that no attempt will be made at more specific designation than nucleus vestibularis for the entire eaudal portion of the vestibulocerebellar nuclear mass. 'This part receives direct vestibular fibers (fig. 19) and also collaterals from the direct vestibular tract which passes to the cerebellum (fig. 29). As shown in figures 19 and 30 , the dendritic processes of many of the cells of the vestibular nucleus are directed so as to come into relationship with the vestibular fibers and also with the spinocerebellar tract. This is true of the larger cells. In the transition zone of the ventral eminence many of the cells send their larger dendrites into the spino-cerebellar tract, but some apparently pass to the vestibular roots (fig. 31) from this region also. 
Of the two types of cells encountered, the large ones with long laterally extended dendrites appear' to represent the more primitive condition, for in the adult frog these are not found in the vestibular nucleus. They still remain, however,

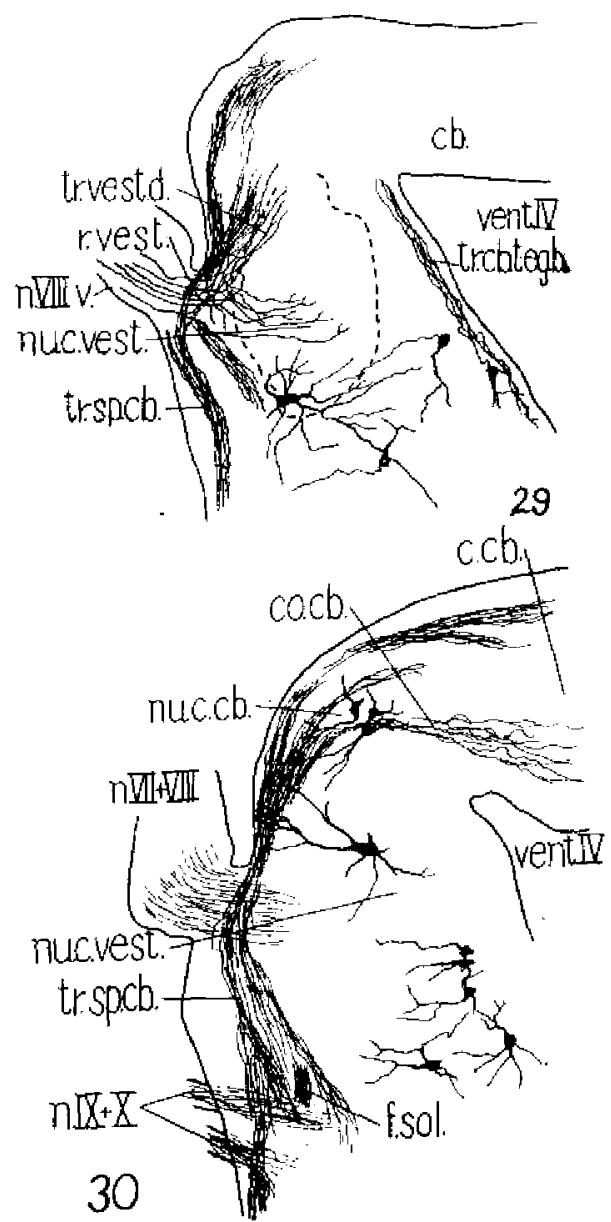

Fig. 29 Horizontal section at entrance of vestibular roots, showing collaterals from the direct vestibulo-cerebellar flbers to the vestibular nucleus. Hyla regilla, 1 -mm. tail length. Golgi method. Camera lucida. $\times 63$.

Fig. 30 Horizontal section througl rostral end of medulla oblongata, showing portions of nucleus cerebelli and nucleus vestibularis and relations of dendritie processes of some of the cells to the spino-cerebellar tract. Hyla regilla of $1-\mathrm{mm}$. tail length. Golgi method. Camera lucida. $\times 63$. 
in the transition zone of the ventral eminence (cf. Larsell, '23, fig. 7).

The rostral region of the common vestibulo-cerebellar nucleus receives collaterals from the spino-cerebellar tract
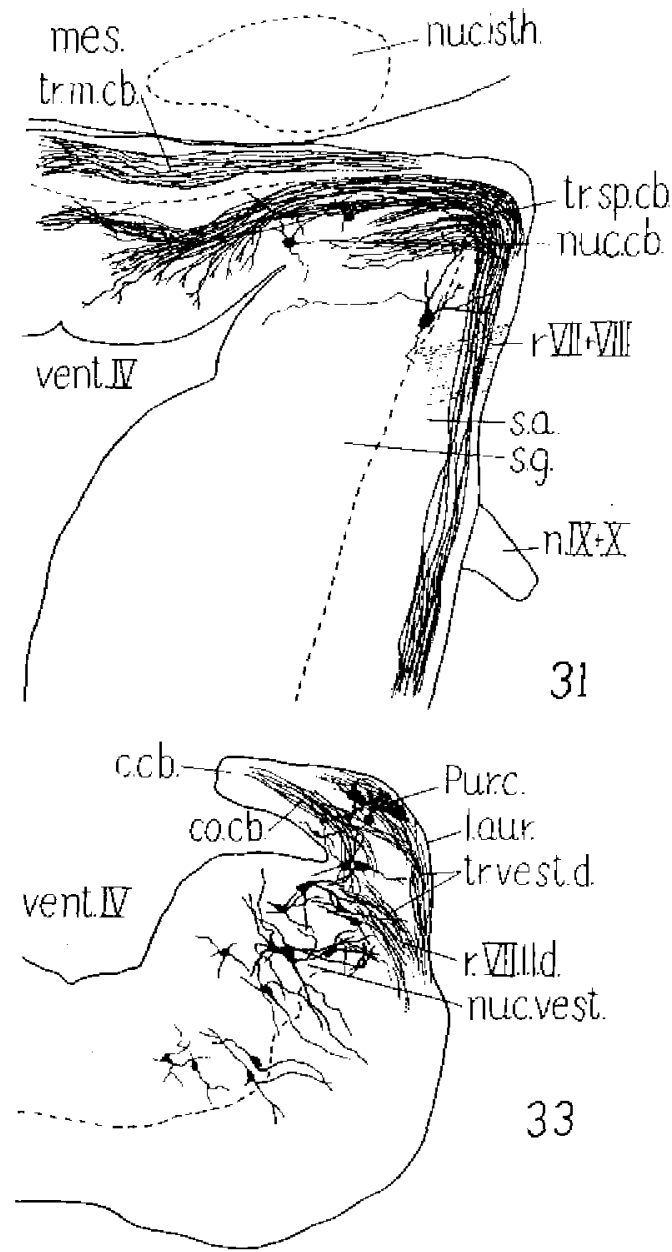

Fig. 31 IIorizontal section through rostral end of medulla oblongata in litrva of $20-\mathrm{mm}$. tail length (32 mm. total length) with well-developed hind legs, showing collaterals from spino-cerebellar tract to nucleus corebelli. Hyla regilla. Golgi method. Camera lucida. $\times 63$.

Fig. 33 Transwerse seetion at rostral level of auricular lobe in Hyla regilla of 42-mm. total length, with small lind legs and no fore legs. Golgi methot. Camera lucida. $\times 52$. 
(fig. 31) in the same manner as does the candal region from the vestibular root. It also receives the direct vestibular fibers as well (figs. 32, 33, and 35). This rostral region differentiates more rapidly and beomes the nucleus eerebelli. In its growth it extends upward more and more toward the hody of the cerebellum (figs. 34 and 35, nuc.cb.) and brings

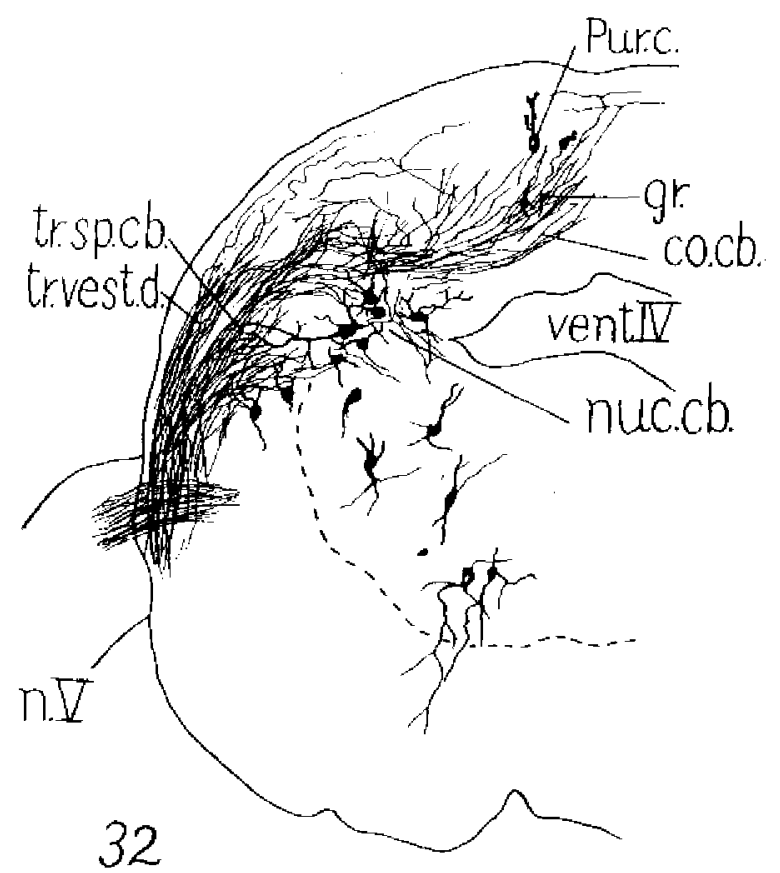

Fig. 32 Transerse section at level of eerebelum and nucleus cerelyelli. Hyla regilla of 10 -mm. tiil iength with well-developorl legs. Golgi method. Camera incida. $\times 76$.

about the fusion of the ventral cerebelar eminence with the corpus cerebelli. It remains continuous with the tegmentum ventrally. Some of the tegmental cells show the primitive arrangement above described, sending their dendrites into the stratum album, whore they come into relationship with several fiber tracts. The axones of the more rostrally located cells of the nucleus cerebelli, as previously stated, pass forward and ventralward as the brachium conjunctivum, while

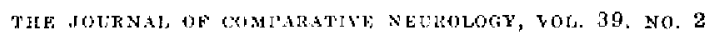


the more caudal cells give off axones which form internal arcuate fibers and the cerebello-tegmental tract (figs. 18, 19, and 21).

In later stages the collaterals from the spino-cerebellar tract to the nucleus cerebelli disappear apparently, for I find no trace of them after metamorphosis is well advanced. The spino-cerebeliar tract passes to the granular layer of the

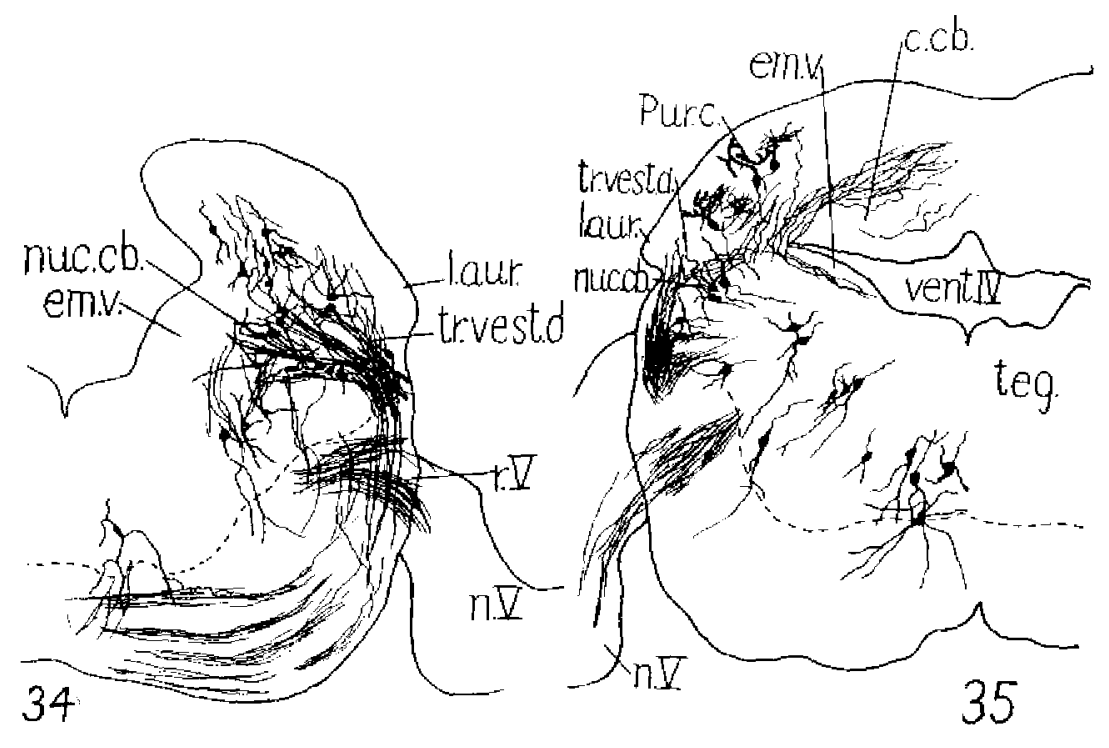

Fig. 34 Transverse section through caudai level of auricular lobe in Hyla regilla of 15 -mm. tail length (27 mm. total length) with well-developed legs. Golgi method. Camera lueida. $\times 43$.

Fig. 35 Transverse section through cerebellum, medulla oblongata, and auricular lobe, showing region of fusion of these parts. Hyla regilla of 10-mm. tail length, with well-developed legs. Golgi method. Camera lueida. $\times 51$.

cerebellum, in which primitive granule colls are formed, and apparently affects the cerebellar nucleus through the intermediation of these granules and the Purkinje cells, rather than directly through the collaterals of the earlier stages. Granule cells can be recognized, although poorly differentiated, in larvae of $40 \mathrm{~mm}$. total length. After metamorphosis is definitely under way, i.e., by the 10-rmm. tail stage, the grantiles are well defined in many of my Golgi series. 
As shown in figure 36 , some cells of the vestibular portion of the nucleus vestibulo-cerebelli also send dendritic processes into the rostral or cerebellar portion, as well as into the vestibular roots (fig. 37), while the axones form interral arcuate fibers.

In the younger stages ( $16 \mathrm{~mm}$. and upward) a group of cells forms a nucleus-like cluster in the region which corresponds to the pons of mammals. This group arises from the ventral portion of the tegmental mass and extends ventrally almost to the surface of the bulb. It is bounded on either side by the great fiber tracts which connect the rostral part of the brain stem with the oblongata and cord. Rostrally this cell mass is continuous with a similar mass in the midbrain, but caudally it ends at the level of the $V$ roots. In later stages and in the adult frog the cells have seattered so that the appearance of a compact nucleus is lost. Fibers pass to this region in late tadpoles and in the adult frog from the ventral cerebellar eminence, and it also receives arcuate fibers from the rostral part of the oblongata. Although no other connections could be established, the connections named and the position of the cell mass suggest an incipient pontile nucleus. Further comparative studies are necessary, however, before this can be established.

\section{PIBER TRAOTS AND CONNEGTIONS}

Reference has been made to most of the fiber-tract connections of the developing cerebellum in the preceding pages, and the tracts in the adult frog have been previously described by the writer. Herrick ('14, '14 a) has set forth the connections in Necturus and in larval Amblystoma, and the present writer ('20) has deseribed the cerebellar tracts and their connections in adult Amblystoma. It is necessary, therefore, to give but a brief summary of these tracts in the developing frog, bearing in mind the fact that prior to metamorphosis these connections are very similar to conditions in Amblystoma. During metamorphosis they more and more approach the conditions of the adult frog. 


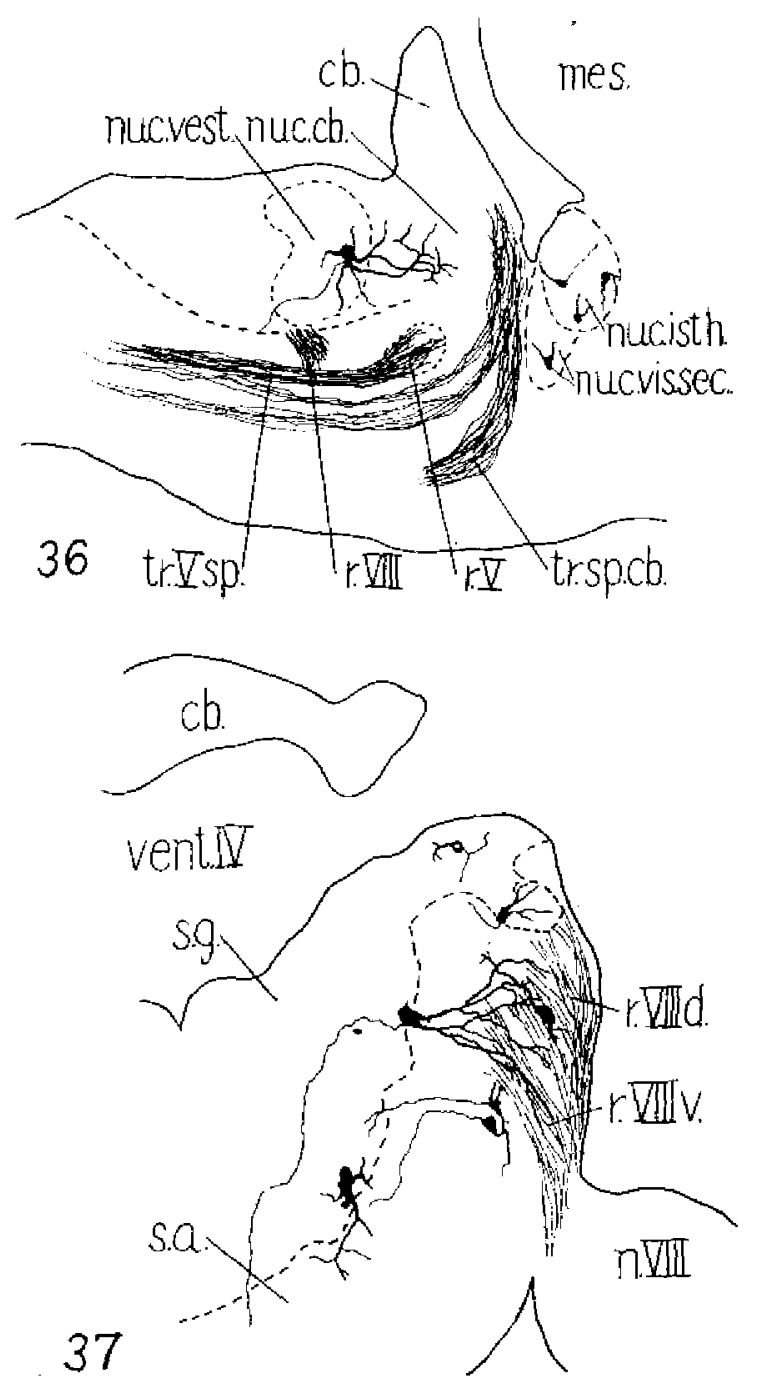

Fig. 36 Para-sagittal section at lateral level, showing one of the cells of the vestibular nuclews with dendritic processes extending into the region of the cerehellar nuclens. Iyla regilla of 10 -mm. tail length, with well-developed legs. Golgi method. Camera lucida. $\times 41$.

Fig. 37 Transverse section at entrance of routs of VIJ nerve. Hyla regilla of 1-mm. tail length. Golgi method. Camera lucira. $\times 63$. 
Tractus spino-cerebellaris. This tract accompanies the spino-tectal tract, as in Amblystoma and the adult frog, to the region below the body of the cerebellum. Here it turns dorsalward (fig. $36, t r . s p . c b$. ) to be distributed as described in the adult frog. In the $16-\mathrm{mm}$. tadpole no definitive spinocorebellar tract is apparent in my Cajal preparations, although other tracts are well stained. Collaterals from the spinal lemniseus, however, are given off which enter the lower part of the corpus on either side, but not near the midplane. Herrick ('14) observed similar collaterals intermingted with definitive spino-cerebellar fibers in larval Amblystoma, and calls attention to them again in his more recent paper (Herrick, '24). Evidently, the 16-mm. Hyla larvae represent an earlier stage of differentiation of this tract. In tadpoles of 39 to $40 \mathrm{~mm}$. a few collaterals from the lemuiseus are still present, but the vast majority of fibers of the spino-cerebellar tract are direct. In late stages of Hyla and in adult Rana I have not succeded in finding collaterals to the cerebellum from the lemniscus.

Tracti restibulo-cerebellaris. These tracts have been described in the previous communication, in part from larval material, so there is little to add. Attention has already been directed to the collaterals which pass to the vestibular nucleus (fig. 29) from the octavo-cerebellar or direct vestibular tract. This nucleus thus receives fibers from both of the vestibular tracts, and gives rise to the vestibulo-cerebellar tract. In the young frog the latter is especially well developed. In some of $\mathrm{my}$ Golgi series dendritic processes from the mucleus cerebelli may also be observed to terminate among the fibers of the vestibular tract. While the vestibular tracts end in the auricular lobe in the frog (fig. 33), the nucleus cerebelli also reeeives impulses from this souree through the dendritic processes just mentioned. In the further development of the cerebellum to the mammalian form, the auricular lobe becomes the floceulus and the nucleus cerebelli becomes differentiated into the several deep cerebellar nuclei of mammals. Acording to Allen ('24), these several nuclei 
are to be considered as composing two distinet functional units, a lateral and a medial nucleus. The medial nucleus "receives both direct vestibular root fibers and fibers from the vestibular nuclei." The dendritic comections above described evidently represent a primitive condition of this connection. With the differentiation of the nucleus cerebelli into several nuclear masses, the more primitive part becomes placed most deeply, as in other parts of the brain. The vestibular comnections are maintained, as Doctor Allen has shown. The floceulus, derived from the auricular lobe, also retains its vestibular connections, although far removed, in the mammal, from the fastigial nucleus.

Radix mesencephalica trigemini. This tract passes through the cerebellum in the tadpole as a rolatively large-fibered and compact bundle. It reaches the anterior medullary velum, but its course beyond this point was not completely studied, beyond ascertaining that its connections were essentially the same as in the adult form and in urodeles. In the larval and young frog material of Hyla there is no indication of relationship with the cerebellum, such as was suggested in my previous paper on the cerebellum of the adult frog (Rana). The brain of Hyla is, however, considerably foreshortened, as compared with Rana, so that a large degree of crowding has resulted in this region, sufficient to obscure the relations of this root.

Tractus trigemino-cerebellaris. Trigeminal fibers to the cerebellum are present as early as the 16-mm. larva (fig. 13). They appear to reach the aurieular lobe onIy, in the larva at this stage. In the young frog (fig. 18) bifurcating fibers from the trigeminus pass to the cerebellum as in the adult.

Tractus tecto-cerebellaris. This tract, present in the adult, was not found in my larval stages.

Tractus mamillo-cerebellaris. A loose bundle of fibers enters the cerebellum rostrally in stages before metamorphosis has progressed far, to terminate in the corpus cerebelli. The course of this tract is toward the hypothalamus, arching ventrally and rostrally through the lateral part of 
the midbrain. It appears to correspond with the mammillocerebellar tract of Necturus (Herrick, '14) and of Amblystoma (Larsell, 20). In late larval stages and in the young frog of $\mathrm{Hyla} I$ was unable to find it.

Tractus cerebello-tegmentalis bulbi. This has already been sufficiently described. It is made up of a bundle of fibers noar the mid-plane which lie a short distance below the ventricular floor. The fibers take their origin from cells in the cerebellar nucleus (fig. 19) and appear to terminate in the tegmental gray of the bulb.

The lateral-line roots, in their relation to the cercbellar development, have received considerable attention in the preceding pages, and there is little to add save that the lateralline $\mathrm{X}$ fibers enter the lateral-line lobe as dorsal and ventral bundles, to accompany the lateral-line VII roots to the auricular lobe.

Commissura cerebelli. This arises in part, in the tadpole, from cells of the ventral eminence which lie medial to the spino-cerebellar and vestibular tracts, as the latter curve upward from the medulla oblongata to pass into the corpus cerebelli and auricular lobe, respectively. Cajal sections reveal very delicate fibers from cells in this location which take part in forming the cerebellar commissure. It receives fibers also from the two tracts just named, especially from the spinocerebellar tract.

Mauthner's cell. Bartelmez ('15) states that these cells disappear as soon as the tail is lost in anuran Amphibia. This I am able to confirm in Hyla, in general, although there is variation as to the exact stage at which the cells are no longer to be recognized. In some specimens they can be recognized up to the time just preceding complete absorption of the tail, sometimes only on one side, sometimes on both sides. The cells in these later stages have every appearance of undergoing degeneration, but this was not checked by the Nissl method, since the specimens of late stages stained by this"method did not show the Mauthner's cells. There is every indication that they are functional up to the 10- or 
12-mm. tail stage, and possibly later, so far as the appearance of the cells may serve as a eriterion of functional activity. This question is worthy of further study, but is not considered especially relevant to the subject under investigation, and has therefore not been pursued.

'To the remaining' cerebellar tracts I have nothing to add beyond the description given in the earlier paper for the adult trog.

\section{SITMMARY}

The cerebellum in the frog develops from a medial portion composed of the corpus cerebelli and the eminentia cerebellaris ventralis, on the one hand, and a lateral portion comprising the auricular lobe. These portions fuse across the floor of the recessus lateralis rhombencephali. The lateral part of the definitive cerebellum represents a portion of the floor of the fossa rhomboidea, as shown by stages of development and by the presence of the anterior diverticulum of the lateral recess, above this region, in later stages and in the adult frog. The auricular lobe corrosponds to the floculus of mammals. In the tadpole it receives both lateral-line and vestibular connections, but after metamorphosis only the latter remain, with the result that the auricular lobe is relatively reduced in size.

The molecular and granular layers of the cerebellum are derived from the stratum album and the stratum griseum, respectively, of the medulla oblongata, and become separated from these, and their elements become differentiated during the course of development of the larva.

The nucleus cerebelli and the nucleus vestibularis are genetically related, and in early stages show considerable similarity of connections which later become modified. The cell pattern of the region from which these nuclei are developed is very simple in the early tadpole. Relatively large cells send dendritic processes laterally which come into relation with several tracts, recalling the condition in the ob-

Iongata of Amblystoma. This condition persists in the adult, to some extent, in the eminentia ventralis. 
The fiber-tract comnections, in general, are similar to those in the adult frog, except that the tecto-cerebellar tract appears to be absent in the tadpole, while lateral-line fibers to the auricular lobe and mammillo-cerebellar fibers are present in the larval stage. 'These latter two groups drop out during metamorphosis.

In general, the changes in the fiber-tract connections of the cerebellum and in the tracts themselves may be interpreted as indicating a transformation from a lateral-line, and possibly gustatory, pre-dominance of impulses to this organ, to a spinal, vestibular, and optic control. These changes in the central nervous system appear to be in keeping with the changes in the habits of the metamorphosed frog as compared with the larva.

\section{LITERATURE CITED}

AlceN, W. F. 1924 Distribution of the fibers originating from the different basal cerebellar nuclei. Jour. Comp. Neur., vol. 36, pp. 399-439.

Bartelmaz, G. W. 1915 Mauthner's cell and the nucleus motorius tegmenti. Jour. Comp. Neur., vol. 25, pp. 87-128.

Hnanck, 9 JUDSon 1914 The cerebellum of Nesturus and other urodele Amphiliz. Jour. Comp. Nemr., vol. 24, pe. 1-29.

1914 a The medulla oblongata of larval Amblystoma. Jour. Comp. Neur., vol. 24 , pp. $343-427$.

1924 Origin and evolution of the eerebellum, A red. Neurol, and I'sycliat, vol. 11, pp. 621-652.

Johnston, J. B. 1902 The brain of Petromyzon. Jour. Comp. Neur., vol. 12 , pp. $1-86$.

KaPPERS, C. U. A. 1920-1921 Vergleichende Anatomie des Nervensystems der Wirbeltiere und des Menschen. Haarlem.

Kingsarry, B. F', 189; The lateral line system of sense orguns in some American Amplibia, and comparison with the dipnoans. Trans. Amer. Mieros. Soe, wol. 17.

1895 On the brain of Necturus maculatus. Jour. Comp. Neur., rol. 5, pp. $139-205$.

IAASELL, O. 1920 The cerebellum of Amblystoma. Jour. Comp. Neur., vol. 31, pp. $259-282$.

1923 The cerebellum of the frog. Jour. Comp. Neur., vol. 36, एj. 89-112.

Nokris, H. W. 1908 The cranial nerves of Amphiuma means. Jour. Comp. Neur, vol. 18, pp. 527-568.

-1913 The cranial nerres of Siren lacertina. Jour. Morph., rol. 24, Pp. $245-338$.

Strong, Olivers, 1895 The eranial nerves of Amphiluia. Jour. Morph., wol. 10, pp. $101-230$. 